\title{
Overview of the precursors and dynamics of the 2012-13 basaltic fissure eruption of Tolbachik Volcano, Kamchatka, Russia
}

\author{
Alexander Belousov ${ }^{\mathrm{a}, *}$, Marina Belousova ${ }^{\mathrm{a}}$, Benjamin Edwards ${ }^{\mathrm{b}}$, Anna Volynets ${ }^{\mathrm{a}}$, Dmitry Melnikov ${ }^{\mathrm{a}}$ \\ a Institute of Volcanology and Seismology, Petropavlovsk-Kamchatsky, Russia \\ b Dickinson College, PA, USA
}

\section{A R T I C L E I N F O}

\section{Article history:}

Received 14 January 2015

Accepted 22 April 2015

Available online 1 May 2015

\section{Keywords:}

Kamchatka

2012-13 Tolbachik eruption

Basaltic volcanism

Eruption dynamics

Eruption monitoring

Eruption forecast

\begin{abstract}
A B S T R A C T
We present a broad overview of the 2012-13 flank fissure eruption of Plosky Tolbachik Volcano in the central Kamchatka Peninsula. The eruption lasted more than nine months and produced approximately $0.55 \mathrm{~km}^{3} \mathrm{DRE}$ (volume recalculated to a density of $2.8 \mathrm{~g} / \mathrm{cm}^{3}$ ) of basaltic trachyandesite magma. The 2012-13 eruption of Tolbachik is one of the most voluminous historical eruptions of mafic magma at subduction related volcanoes globally, and it is the second largest at Kamchatka. The eruption was preceded by five months of elevated seismicity and ground inflation, both of which peaked a day before the eruption commenced on 27 November 2012. The batch of high-Al magma ascended from depths of 5-10 km; its apical part contained 54-55 wt.\% $\mathrm{SiO}_{2}$, and the main body $52-53 \mathrm{wt} . \% \mathrm{SiO}_{2}$. The eruption started by the opening of a $6 \mathrm{~km}$-long radial fissure on the southwestern slope of the volcano that fed multi-vent phreatomagmatic and magmatic explosive activity, as well as intensive effusion of lava with an initial discharge of $>440 \mathrm{~m}^{3} / \mathrm{s}$. After 10 days the eruption continued only at the lower part of the fissure, where explosive and effusive activity of Hawaiian-Strombolian type occurred from a lava pond in the crater of the main growing scoria cone. The discharge rate for the nine month long, effusion-dominated eruption gradually declined from 140 to $18 \mathrm{~m}^{3} / \mathrm{s}$ and formed a compound lava field with a total area of $\sim 36 \mathrm{~km}^{2}$; the effusive activity evolved from high-discharge channel-fed 'a'a lavas to dominantly low-discharge tube-fed pahoehoe lavas. On 23 August, the effusion of lava ceased and the intra-crater lava pond drained. Weak Strombolian-type explosions continued for several more days on the crater bottom until the end of the eruption around 5 September 2013. Based on a broad array of new data collected during this eruption, we develop a model for the magma storage and transport system of Plosky Tolbachik that links the storage zones of the two main genetically related magma types of the volcano (high-Al and high-Mg basalts) with the clusters of local seismicity. The model explains why precursory seismicity and dynamics of the 2012-13 eruption was drastically different from those of the previous eruption of the volcano in 1975-76.
\end{abstract}

(c) 2015 Elsevier B.V. All rights reserved.

\section{Introduction}

The 2012-13 flank fissure eruption of Plosky Tolbachik Volcano (Samoylenko et al., 2012; Edwards et al., 2013; Dvigalo et al., 2014) produced approximately $0.55 \mathrm{~km}^{3}$ DRE (Dense Rock Equivalent) of basaltic trachyandesite magma (here and later the DRE is a volume recalculated to density of $2800 \mathrm{~kg} / \mathrm{m}^{3}$ for non-vesiculated magma taken from average lava densities of $2500 \mathrm{~kg} / \mathrm{m}^{3}$ and pyroclast densities of $1100 \mathrm{~kg} / \mathrm{m}^{3}$ ). It is the second largest historical eruption of mafic magma in Kamchatka (the largest was the 1975-76 fissure eruption at the same volcano). The 2012-13 eruption lasted more than nine months, and its different stages were studied by several teams of scientists focused on various aspects of the eruptive process. We present here our own observations of the eruption dynamics collected during six long-term field campaigns

* Corresponding author at: Institute of Volcanology and Seismology, Piip Boulevard 9 Petropavlovsk-Kamchatsky 683006, Russia. Tel.: + 79140207119.

E-mail addresses: belousov@mail.ru, belousovsasha@yahoo.com (A. Belousov). on the volcano, combined with the published observations made by the other teams. The goal of this paper is to present a general overview of the 2012-13 eruption precursors and dynamics as well as interpretations of the observed variations in eruption mechanisms.

\subsection{General geology and volcanology of the Tolbachik volcanic complex}

Tolbachik is comparatively well-studied volcanic complex in central Kamchatka. It was first mentioned in the works of the famous 18th century naturalists Krasheninnikov (1764) and Steller (1774, 2003). Piip $(1946,1956)$ described the general geological features of the volcano and its eruption in 1941. A large volume of geological, geochemical, and geophysical data was also collected during the 1975-76 eruption of the volcano which became known as 'The Great Tolbachik Fissure Eruption' (GTFE; Fedotov et al., 1980; Fedotov and Markhinin, 1983; Fedotov, 1984).

Tolbachik encompasses the southern part of the Klyuchevskaya Volcanic Group, which is located inside the Central Kamchatka Depression 


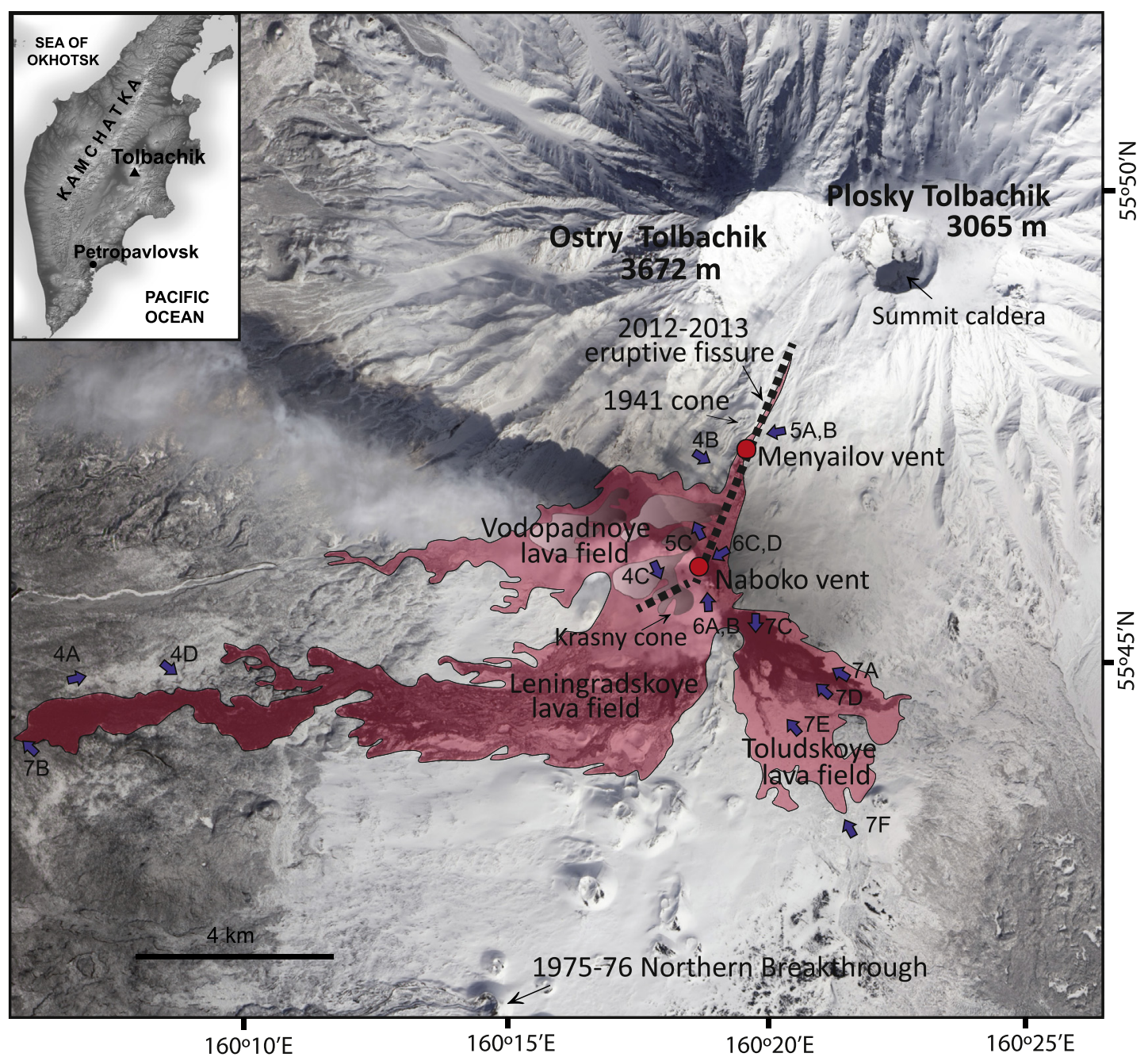

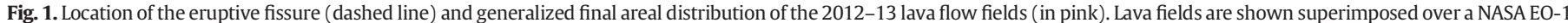

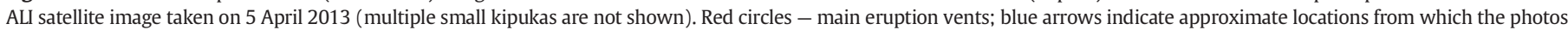

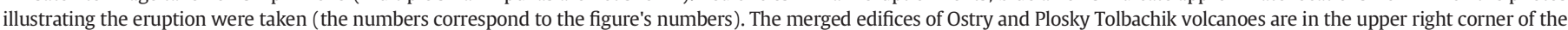

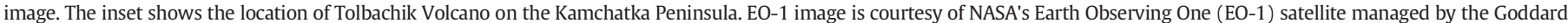
Space Flight Center (http://eo1.gsfc.nasa.gov)

(Fig. 1). The group is well-known as the most productive and diverse subduction-related volcanic area on Earth with compositions of the erupting magmas ranging from basalt to dacite (Piip, 1956; Portnyagin et al., 2007). The volcanism of the group is driven by the subduction of the Pacific Plate under the Okhotsk microplate with an average convergence rate of $9 \mathrm{~cm} / \mathrm{yr}$. The unusually high magma production rate is likely related to both the very fast subduction and the proximity of the corner of the Pacific Plate (Yogodzinski et al., 2001).

The first eruptions in the Klyuchevskaya Volcanic Group started in the Early Pleistocene with voluminous effusions of basaltic andesite rich in plagioclase megacrysts that built a broad lava plateau. Later, several high stratovolcanoes were constructed (Piip, 1956; Churikova et al., 2015). At present, some of these volcanoes (Krestovsky, Kamen, Zimina, Gorny Zub, Bol'shaya and Malaya Udina) are considered to be extinct and Ushkovsky is dormant, while Klyuchevskoy, Bezymianny, and Tolbachik are very active. Klyuchevskoy, the youngest and highest volcano (7000 years old; 4800 masl (meters above sea level)) has a basaltic to basaltic andesite composition and has erupted almost continuously throughout historical time (Piip, 1956; Guschenko, 1979; Ozerov, 2000; http://www.volcano.si.edu/volcano.cfm?vn=300260).

The edifice of Tolbachik has a basal diameter of $25 \mathrm{~km}$ and comprises two merged stratocones: Ostry (pointed summit) with an elevation of 3672 masl and Plosky (flat summit) with an elevation of 3065 masl.
Both edifices grew simultaneously in the Pleistocene, but then Ostry Tolbachik ceased its activity, while Plosky Tolbachik continued to erupt throughout the Holocene (Braitseva et al., 1983). In the beginning of the Holocene, Plosky Tolbachik underwent an important transformation of eruption activity: two long rift-like radial structures were formed on its northeastern (azimuth $45^{\circ}$; length $11 \mathrm{~km}$ ) and southwestern (azimuth $203^{\circ}$; length $35 \mathrm{~km}$ ) slopes. Subsequent eruptions of basaltic magma along these zones formed numerous monogenetic scoria cones and lava flows. Approximately $80 \mathrm{~km}^{3}$ of magma were erupted during the Holocene through the southwest rift that is locally referred to as "Tolbachinsky Dol" (Braitseva et al., 1984).

Lateral withdrawal of magma from a shallow magma chamber beneath Plosky Tolbachik associated with the rift eruptions led to repeated formation of subsidence calderas on the volcano's summit (Fedotov et al., 1980). Between the subsidence episodes, the summit eruptions partially refilled the calderas with horizontal layers of lava. Circular escarpments of three nested calderas are currently visible on the flat summit of the volcano. The oldest and largest is a $3 \mathrm{~km}$-wide caldera that likely formed in the beginning of the Holocene, and the youngest is a $1.5 \mathrm{~km}$-wide caldera that subsided during the 1975-76 fissure eruption in the southwest rift of the volcano (Fedotov et al., 1980; Dvigalo et al., 1991). In the Early Holocene, the southern slope of the twinned volcanic edifice experienced large-scale lateral collapse that affected 
mostly the cone of Ostry Tolbachik and, to a much lesser degree, the cone of Plosky Tolbachik (Dvigalo et al., 1991).

Tolbachik erupts basalts of two different types (Fig. 2): high-alumina and high-magnesium (Volynets et al., 1983). The high-Al basalts comprise more than $90 \%$ of the erupted material (Braitseva et al., 1984). They erupt through the both of the rift systems as well as through the volcano's summit. This magma originates from shallow depths (estimated 5-8 km) and produces Strombolian to Hawaiian eruptions that form relatively small scoria cones and both 'a'a and pahoehoe-type lava flows. Tolbachik is the only volcano in Kamchatka that has produced fluid pahoehoe-type lavas in historical times. Eruptive products of the high-Al magma of Tolbachik commonly bear twinned plagioclase phenocrysts up to several $\mathrm{cm}$ across. Tephras of these eruptions contain lapilli-sized megacrysts (referred to as "crystal lapilli") separated by explosive vesiculation from the parental magma. The largest (up to $4 \mathrm{~cm}$ ), well-developed (almost spherical with multiple twinned plates) crystal lapilli are found around the summit calderas of Tolbachik. Probably these megacrysts accumulate/grow inside the shallow magma storage zone for the high-Al basaltic magma located beneath the summit of the volcano.

The high-Mg olivine-bearing magma erupts only through the southwest rift, where its products comprise less than $10 \%$ by volume. This magma ascends from greater depths (estimated $>20 \mathrm{~km}$ ) and produces highly explosive Ultrastrombolian to Subplinian eruptions. The eruptive products compose large scoria cones (with associated thick and widespread tephra fallout deposits) as well as 'a'a-type lava flows. Tephrochronological investigations have shown that the first eruptions of high-Mg type started at the southwest rift 2000 years ago (Braitseva et al., 1984). During some eruptions within the southwest rift zone the high-Mg and high-Al magma types have interacted to produce hybrid lavas and tephra (the magmas of intermediate composition of Volynets et al., 1983).

Only high-Mg magma was erupted during the 1941 activity, and only high-Al magma was erupted during the 2012-13, but both

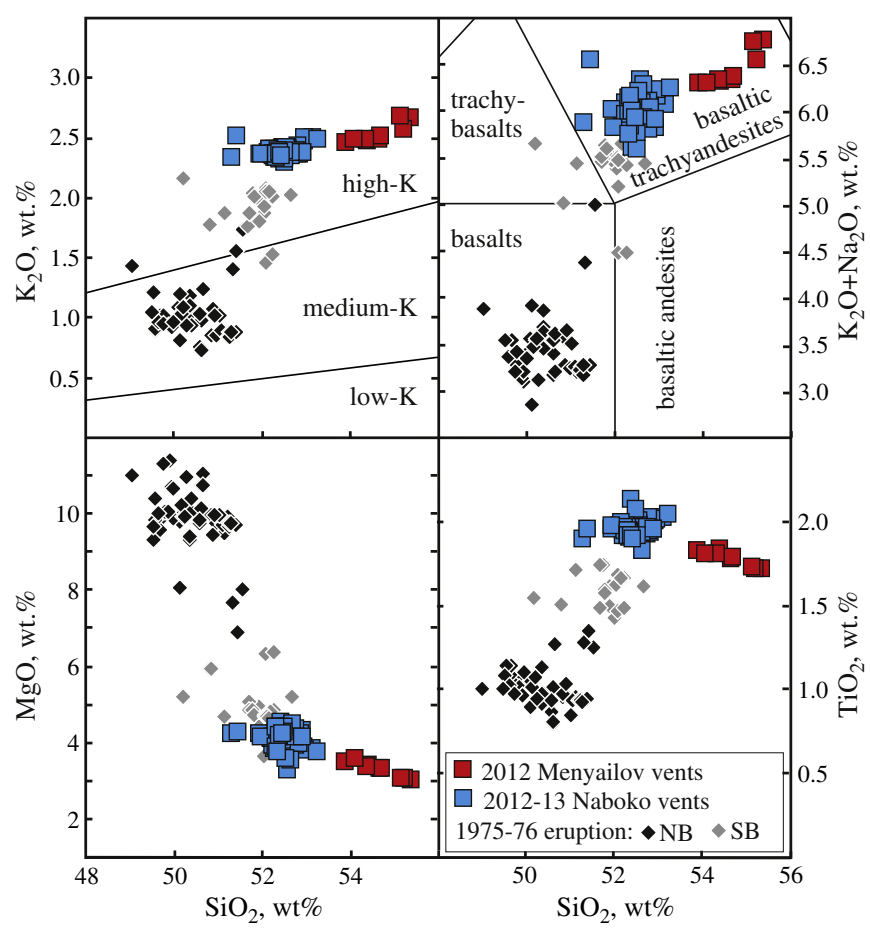

Fig. 2. Harker diagrams for the products of the 1975-76 and 2012-13 eruptions of Tolbachik. NB and SB indicate Northern and Southern Breakthroughs of the 1975-76 eruption. Discrimination lines on $\mathrm{K}_{2} \mathrm{O}-\mathrm{SiO}_{2}$ and $\mathrm{K}_{2} \mathrm{O}+\mathrm{Na}_{2} \mathrm{O}-\mathrm{SiO}_{2}$ diagrams are from Le Maitre (1989). magma types as well as the hybrids were erupted in the 1975-76. Products of Tolbachik during last 2000 years (including those of the 1941, 1975-76, and 2012-13 eruptions) are genetically related to each other and originate by fractionation from a common primary magma in the crust; magma fractionation occurs in open system with periodic replenishment, tapping and fractionation (Portnyagin et al., 2015).

\subsection{Pre-2012 eruptions}

The period for historical documentation of eruptions at Tolbachik starts only from the early 18th century. However since then all of the principle eruption styles recorded in deposits of the volcano have been observed. Altogether, 14 eruptions are listed for the historical period: 1740, 1769, 1788-90, 1793, 1904, 1931, 1937, 1939-41, 1954, 1961-62, 1964, 1967-70, 1975-76 and 2012-13 (Guschenko, 1979; http://www.volcano.si.edu/volcano.cfm?vn=300240). Details of the first historical eruptions are not known. In the periods 1939-1941 and $1967-1970$ a persistent lava lake existed in a pit crater $0.35-0.4 \mathrm{~km}$ wide and $0.2 \mathrm{~km}$ deep on the summit of the volcano (Dvigalo et al., 1991). Explosive activity of the lava lake occasionally ejected bombs and ash as well as Pele's hair. The 1941 and 1975-76 flank eruptions started with an increase in the summit activity and then developed into flank eruptions along the southwest rift (Piip, 1946; Fedotov and Markhinin, 1983; Fedotov, 1984).

The 1941 flank eruption took place at a distance $4.5 \mathrm{~km}$ from the volcano summit at an elevation of 1950 masl and lasted 7 days (Table 1). The erupted high-Mg magma had a volume of $0.016 \mathrm{~km}^{3}$ DRE. It constructed a scoria cone $100 \mathrm{~m}$ high with a basal diameter of $800 \mathrm{~m}$ and formed an 'a'a-type lava flow $5 \mathrm{~km}$ long (Piip, 1946).

The 1975-76 eruption of Tolbachik is among the six largest historic fissure eruptions globally, and it produced the largest historical lava flow in Kamchatka (Fedotov et al., 1980; Fedotov and Markhinin, 1983; Fedotov, 1984). The eruption consisted of two distinct episodes (Northern and Southern Breakthroughs) separated in time and space (Table 1). The Northern Breakthrough began first and was preceded by a 9-day-long swarm of high-energy earthquakes with magnitude (M) 2-5 that were located below the breakthrough area at depths up to $20 \mathrm{~km}$ (Tokarev, 1978). The breakthrough started along a $300 \mathrm{~m}$-long fissure at a distance $18 \mathrm{~km}$ from the volcano summit at an elevation of 880 masl and lasted 70 days. The highly explosive (Subplinian-Ultrastrombolian) eruption produced $0.57 \mathrm{~km}^{3}$ DRE of high-Mg magma. The eruption sequentially constructed three large scoria cones up to $300 \mathrm{~m}$ high and formed an 'a'a-type lava flow $5 \mathrm{~km}$ long. While the eruption of the Northern Breakthrough was still in progress, seismic activity started at shallow levels $(<2 \mathrm{~km})$ under the edifice of Plosky Tolbachik. This seismicity marked the initiation of lateral migration of high-Al magma from the shallow chamber (located under the volcano summit) along the southwest rift. Intermingled magmas of intermediate composition were erupted at the very end of the Northern Breakthrough and the very beginning of the Southern Breakthrough.

The Southern Breakthrough started two days after the cessation of the Northern Breakthrough at a distance $27.5 \mathrm{~km}$ from the volcano summit at an elevation of 350 masl (Fedotov et al., 1980). The eruption was preceded by a few days of shallow-level earthquakes between the vent area and Plosky Tolbachik; the strongest of them $(M=4.3)$ occurred in the area between the Northern and the Southern Breakthroughs. The volume of the erupted high-Al magma was $0.87 \mathrm{~km}^{3}$ DRE. Large phenocrysts of plagioclase (including crystal lapilli up to $3.5 \mathrm{~cm}$ across) were characteristic of the erupted products. The Strombolian eruption lasted 450 days; it had a low explosivity and constructed a $165 \mathrm{~m}$ high scoria cone as well as a compound 'a'a and pahoehoe-type lava field $9 \mathrm{~km}$ long and up to $6 \mathrm{~km}$ wide. Simultaneously with the eruption, a new $1.5 \mathrm{~km}$-wide subsidence caldera was formed on the summit of Plosky Tolbachik. 
Characteristics of historical fissure eruptions of Plosky Tolbachik.

\begin{tabular}{|c|c|c|c|c|}
\hline & \multicolumn{4}{|l|}{ Eruption (year) } \\
\hline & \multirow[t]{2}{*}{1941} & \multicolumn{2}{|l|}{$1975-76$} & \multirow[t]{2}{*}{$2012-13^{\text {** }}$} \\
\hline & & N Breakthrough & S Breakthrough & \\
\hline Duration (days) & 7 & 70 & 450 & 280 \\
\hline Magma type $\left(\mathrm{SiO}_{2}\right.$ wt.\%) & High-Mg (49-50) & High-Mg (49-51) & High-Al (50-53) & High-Al (52-55) \\
\hline Distance from summit $(\mathrm{km})^{*}$ & 4.5 & 18 & 27.5 & $7.5(3.5-8.5)$ \\
\hline Average magma discharge $\left(\mathrm{m}^{3} / \mathrm{s}\right)$ & 27 & 95 & 22 & 23 \\
\hline Max magma discharge $\left(\mathrm{m}^{3} / \mathrm{s}\right)$ & No data & 112 & 80 & 440 \\
\hline Max $\mathrm{H}$ of scoria cone $(\mathrm{s})(\mathrm{m})$ & 100 & 300 & 160 & 125 \\
\hline Max L of lava flows (km) & 5 & 5 & 9 & 17.8 \\
\hline A of lava flows $\left(\mathrm{km}^{2}\right)$ & 1.8 & 9 & 36 & 36 \\
\hline V of lava flows $\left(\mathrm{km}^{3}\right)$ & $0.014 / 0.0125 \mathrm{DRE}$ & $0.22 / 0.2 \mathrm{DRE}$ & $0.96 / 0.86 \mathrm{DRE}$ & $0.6 / 0.54 \mathrm{DRE}$ \\
\hline V of pyroclasts $\left(\mathrm{km}^{3}\right)$ & $0.01 / 0.004 \mathrm{DRE}$ & 0.95/0.37 DRE & 0.03/0.012 DRE & 0.02/0.008 DRE \\
\hline Total V $\left(\mathrm{km}^{3}\right)$ & $0.016 \mathrm{DRE}$ & $0.57 \mathrm{DRE}$ & 0.87 DRE & 0.55 DRE \\
\hline Reference & Piip (1946) & Fedotov (1984) & Fedotov (1984) & \\
\hline
\end{tabular}

$\mathrm{H}$ - height, $\mathrm{L}$ - length, $\mathrm{A}$ - area, $\mathrm{V}$ - volume.

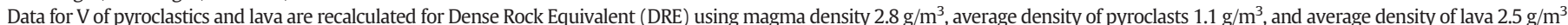

* Distance from the caldera center to the largest scoria cone of the eruption; for the 2012-13 eruption also distances to proximal and distal terminations of the eruptive fissure are indicated in parenthesis.

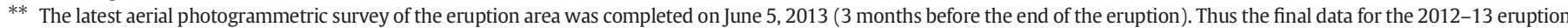

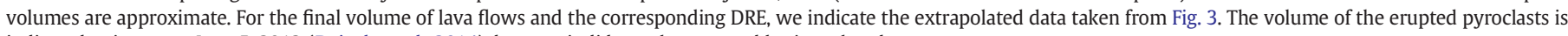
indicated as it was on June 5, 2013 (Dvigalo et al., 2014), because it did not change notably since that date.

\section{The 2012-2013 eruption forecast and the precursory events}

After the 1975-76 eruption, the long-term forecast for the time of the next eruption of Plosky Tolbachik was based on the average rate of magma production of the volcano during the Holocene that was estimated as $0.2 \mathrm{~m}^{3} / \mathrm{s}$ (Braitseva et al., 1984). It was believed that after the 1975-76 voluminous eruption the volcano would need at least 200 years of repose to accumulate enough magma in its feeding system for the next eruption of comparable scale (Fedotov, 1984; Dvigalo et al., 1991). However, the forecast did not exclude the possibility of minor eruptions any time before that. Based on general scenarios of the previous eruptions, the next minor eruption of Tolbachik was expected to start inside the summit caldera (possibly with formation of a new persistent lava lake). Obviously, the timing, scale, and character of the 2012-13 eruption turned out to be completely different from those that were forecast.

The algorithm of the short-term forecast was based on the assumption that the next eruption would be preceded by a long (of the order of 10 days) and intense (up to M5) swarm of volcanic earthquakes gradually ascending from depth (of the order of $20 \mathrm{~km}$ ) in a manner similar to the one that preceded the 1975-76 eruption (Tokarev, 1978). However, the preceding seismicity for the 2012-13 eruption was much weaker and occurred only at shallow depths of $<10 \mathrm{~km}$ (Saltykov et al., 2012; Kugaenko et al., 2015; Senyukov et al., 2015). Relatively strong earthquakes $(M=3-4)$ started below the volcano less than a day before the eruption commenced. The existing procedures for both the processing of seismic data and the decision-making were not fast enough to issue a timely eruption forecast. The definite seismic precursors of the 2012-13 eruption were discovered later (post factum), when detailed analysis of the seismic records had been completed.

Seismic precursors of the 2012-13 eruption are analyzed in detail by Saltykov et al. (2012), Kugaenko et al. (2015), Senyukov et al. (2015), and V. Ivanov (written communication). A network of modern digital seismic stations was installed in the area a decade before the eruption. In general, seismicity under Tolbachik was very low during the preeruption period and did not show obvious escalation until the day before the eruption started on 27 November. However, statistical analysis shows that the first signs of the unrest appeared 5 months earlier, in July 2012, when seismic activity in the region became slightly higher than the average level (Kugaenko et al., 2015). Starting in July, both the number and energy of earthquakes started to increase gradually. Relatively strong ( $M=3-4)$ and frequent earthquakes (the seismic swarm) started $\sim 16 \mathrm{~h}$ before the eruption. The hypocenters of the swarm were located at depths of $<10 \mathrm{~km}$; most of them $<5 \mathrm{~km}$. At first they were centered below the volcano summit caldera. One earthquake with $M=3-4$ occurred at 17:15 local time (here and after the UTC time = local time-12 h) under the southern slope of the volcano in the area of the future eruption. This earthquake was followed by the first pulse of intensive spasmodic seismic tremor $\sim 45 \mathrm{~min}$ long (Fig. 4 in Senyukov et al., 2015). Then seismic activity notably decreased and in $2 \mathrm{~h}$ culminated in multiple earthquakes under the southern slope. The earthquakes were followed by second pulse of volcanic tremor that became continuous. At that time the volcano was completely obscured by dense clouds, and it is not known precisely which of the two pulses of seismic tremor marks the initiation of the eruption. A possible sequence of the eruptive events is reconstructed in the description of the initial stage of the eruption.

Ground deformations associated with the 2012-13 eruption are investigated by Kugaenko et al. (2015). Continuous real-time monitoring of ground deformation specifically focused on Tolbachik was not organized before the eruption. The network of GPS stations nearest to the volcano was located around nearby Bezymianny Volcano $(20 \mathrm{~km}$ to the NE). These stations recorded the data to their internal memory but did not relay them in real time; thus these data became available only several months after the eruption started. Analysis of the data shows that these stations started to record gradual inflation of the area around Tolbachik approximately 5 months before the eruption commenced (almost simultaneously with the seismic unrest). At the moment the eruption began, the stations started to register sharp deflation, clearly indicating that the recorded deformation was caused by changes in magma volume under Tolbachik. The deflation was so intense that it was registered by GPS stations at distances up to $60 \mathrm{~km}$ from the volcano.

No other precursory events, e.g., increase of the fumarole activity and/or thermal anomaly inside the summit caldera were observed before the eruption.

\section{The $\mathbf{2 0 1 2 - 2 0 1 3}$ eruption dynamics}

Most of the on-site observational data about the eruption dynamics were collected by teams of volcanologists from the Institute of Volcanology and Seismology at Kamchatka (formally combined in the specially organized Tolbachik Expedition), which sequentially replaced 
one another in field camps on the lower part of the volcano's flank. This work was a challenge, especially during the winter period, because the two huts previously used for camping were destroyed by the lava flows during the first few days of the eruption. Important data were also obtained during helicopter overflights of the area (on November 29, December 13, December 27, 2012 and on February 15 and June 5, 2013) when aerial photogrammetric and Forward Looking Infra-red (FLIR) surveys of the growing lava field were completed (Droznin et al., 2014; Dvigalo et al., 2014). Images from various space satellites were used to obtain broad overviews of the eruption progress (Melnikov and Volynets, 2015).

The nine month long eruption can be formally subdivided into three major stages: initial, main, and final (Fig. 3). The initial and final stages had relatively short durations, lasting about 10 days, but were very dynamic, during which both the eruption style and intensity experienced rapid changes. The main stage lasted more than 8 months and was characterized by a relatively uniform eruption style with a gradual decline in the overall eruption intensity, although notable short-lived fluctuations were observed.

\subsection{The initial stage}

First observations of the new eruption were conducted from Kozyrevsk which is the nearest settlement to the volcano located $40 \mathrm{~km}$ to the west. A red glow from the eruption first became visible through the snowstorm haze at 10 PM on November 27, 2012. During the night of 27-28 November gray ash fell, forming two layers across the road between Klyuchi and Kozyrevsk (Melnikov and Volynets, 2015). Along the axis of the fallout, $0.7 \mathrm{~kg} / \mathrm{m}^{2}$ of fine-medium ash was deposited at distances $50-65 \mathrm{~km}$ from the volcano. This fallout was the most extensive of the entire eruption. The next day the weather was still poor; sounds of explosions were periodically heard in Kozyrevsk and also in Klyuchi, $70 \mathrm{~km}$ north of the eruption site. It was also reported that the level of water fluctuated notably (fountains up to $5 \mathrm{~cm}$ ) in the holes that fisherman drilled in the ice of the Kamchatka River (pers. com. of Yu. Demyanchuk). The first clear views of the eruption site became possible late in the evening on 28 November. Several points of moderate explosive activity grouped into two main clusters were located along the newly formed fissure on the southern flank of the volcano. By visual estimations the eruption ash clouds reached $3 \mathrm{~km}$ in height. Some vents emitted lava flows that moved toward the west-southwest. The first detailed observations of the new eruption were made from helicopter on 29 November (Fig. 4). The overflight observations together with the data from later aerial photography (Dvigalo et al., 2014), infrared surveys (Droznin et al., 2014), and investigation of the first erupted products, are the basis for the following reconstruction of the initial activity of the eruption.

The eruption started with the opening of an eruptive fissure at the southern foot of the volcano in the axial zone of its southwest rift (Figs. 1 and 4a). The fissure is a linear extensional structure $6 \mathrm{~km}$ long, and oriented along an average azimuth of $200^{\circ}$. It comprises multiple chains of short fractures (each $<200 \mathrm{~m}$ long) that spanned elevations from 1460 to 2358 masl (Dvigalo et al., 2014). The fissure dissected the gently inclined, hilly terrain comprising friable (locally weakly agglutinated) scoria deposits of previous flank basaltic eruptions of the volcano. The upper part of the fissure crossed the east foot of the 1941 scoria cone, and its lower part crossed the Krasny scoria cone (whose age is $<1000 \mathrm{yr} \mathrm{BP}$ according to Braitseva et al. (1983)) where the lowermost terminus of the fissure made a $20^{\circ}$ turn toward the southwest.

Probably the eruption began from two separate episodes of vigorous explosive activity. The initial episode of explosive activity generated seismic tremor that started after the 17:15 earthquake. Then, after $2 \mathrm{~h}$ of relative quiescence, at $\sim 20: 00$ the second pulse of earthquakes and the subsequent increase of seismic tremor marked further opening/elongation of the eruption fissure and intensification of the eruption process. These two separate eruptive episodes may correspond to the two ash layers deposited on 27-28 November (Fig. 4 in Senyukov et al., 2015). The lower ash is poorly sorted, comprising a mixture of bubbly basaltic glass shards (pulverized fresh magma) and heterolithologic blocky particles (fragmented country rocks); large particles are coated by abundant fine particles of fragmented rocks. The lower ash probably has a mixed origin (phreatomagmatic and magmatic): the rising magma was fragmented by exsolution of volatiles and by explosive interaction with ground water/permafrost. The upper ash is better sorted and comprises shiny bubbly basaltic glass shards (pulverized fresh magma) with a few blocky particles of fragmented country rock. The upper ash is probably mostly magmatic in origin, with less evidence for magmawater/permafrost interaction.

During the first few days of the eruption, the explosive activity occurred through numerous vents scattered along the entire length of the fissure (Fig. 4b and c). Many of the vents initially ejected dark ash clouds and ballistics; these explosions are interpreted to have been phreatomagmatic in origin. The phreatomagmatic explosions formed multiple funnel-shaped craters up to $100 \mathrm{~m}$ across and excavated many meters down into the pre-existing rocks (Fig. 5a and b). Then some vents ceased to erupt, while the activity at the others changed to purely magmatic and transitioned into lava fountains that ejected incandescent masses of fluid lava up to $200 \mathrm{~m}$ above the vents.

During the overflight on 29 November, both types of explosive activity, phreatomagmatic and magmatic, were in progress from different vents (Fig. 4). Two groups of vents were most active: one in the middle part of the eruptive fissure at an elevation of 1850 masl (referred to as the Menyailov vents), and the others at lower elevations of 1740 masl (referred to as the Naboko vents). The vents were named after well-known Russian volcanologists A.A. Menyailov (1907-1985) and S.I. Naboko (1909-2005).

Probably simultaneously with the lava fountains, the first lava flows started to pour from several vents along the fissure. The uppermost lava vents were at an elevation of 2000 masl on the southeastern foot of the 1941 AD scoria cone; the lowermost lava vents were at an elevation of 1500 masl on the western foot of Krasny cone. In some places

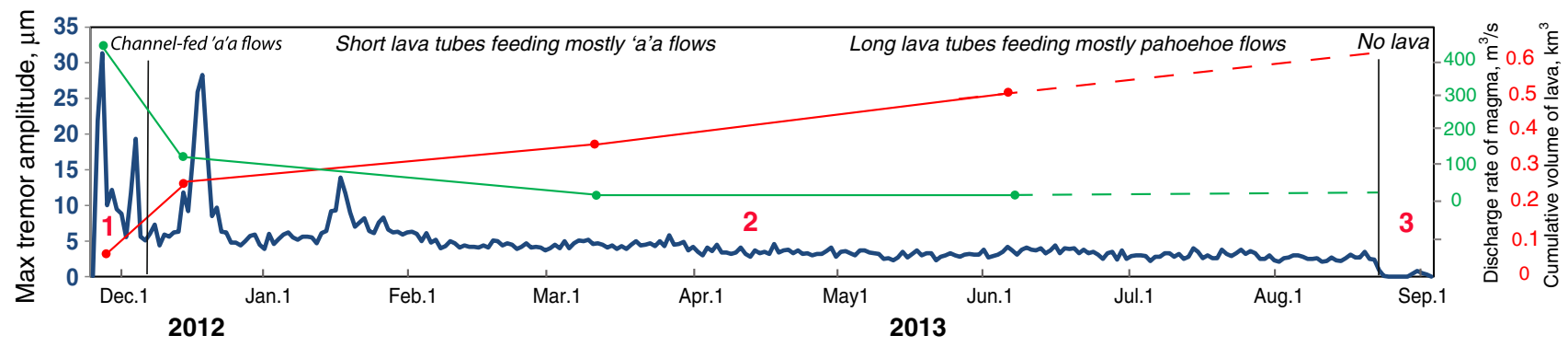

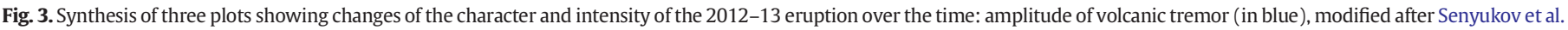

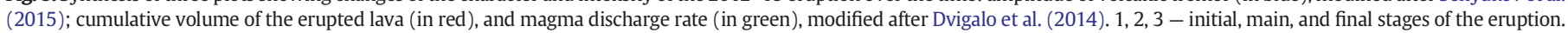
Characteristics of effusive activity of the eruption are in italic. 
(a)

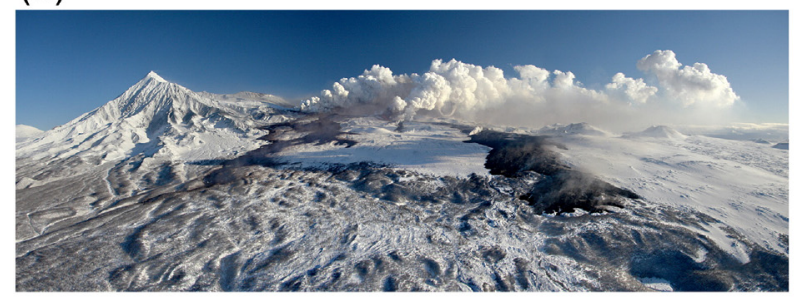

(c)

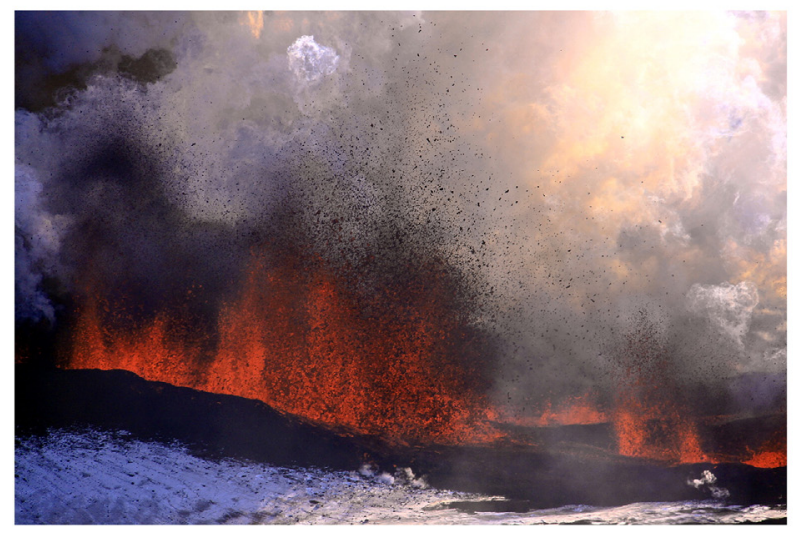

(b)

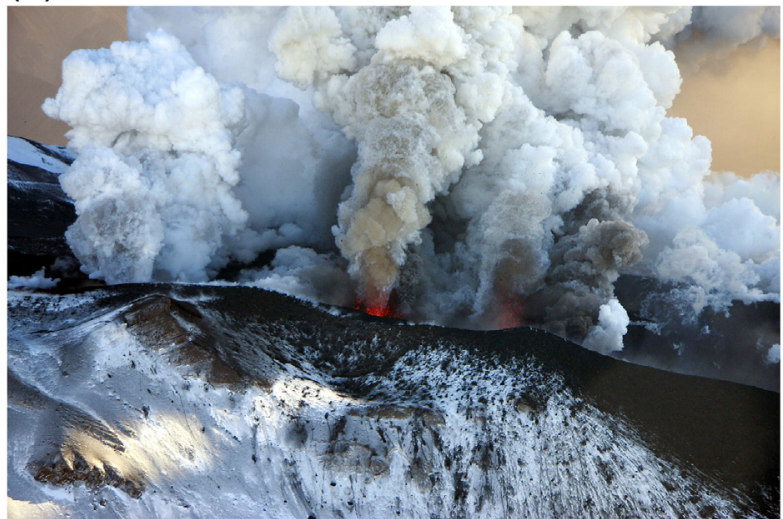

(d)

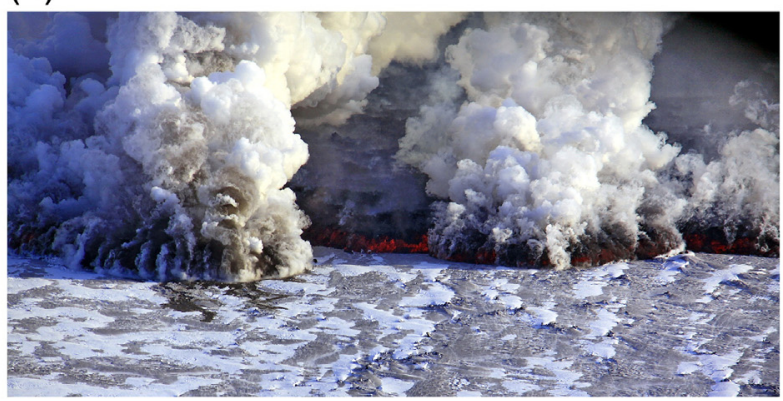

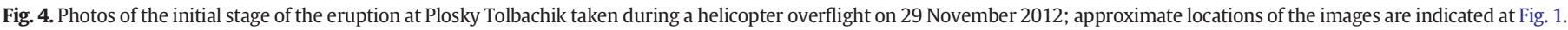

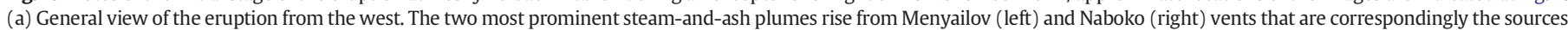

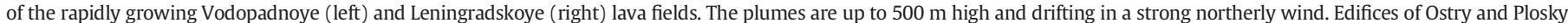

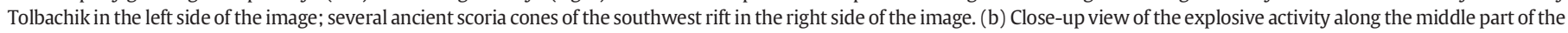

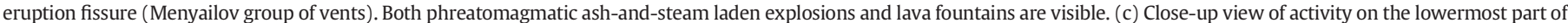

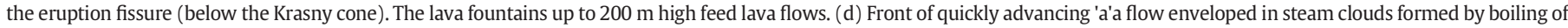
meltwater at the lava flow/substrate boundary. Photos 4A and B are courtesy of A. Sokorenko; 4C and D are courtesy of S. Samoilenko.

magma did not ascend directly upward to the ground surface, but at depths of tens of meters it intruded and spread laterally (as a shallow sill) into low-density friable scoria deposits from past eruptions. Then the sill transformed into a shallow-level, 'subterranean' lava flow that dragged away the old pyroclasts on its surface (Fig. 5c). In several places the lava remobilized and carried away substantial volumes of the old scoria; the process was especially extensive at elevations of 1700-1800 masl, where a large (up to $300 \mathrm{~m}$ wide and $1 \mathrm{~km}$ long) subsidence structure formed. Eventually the lava appeared at the ground surface from the rubble of the displaced pyroclasts at distances several hundred meters downslope from the eruptive fissure. The magma stalled/spread laterally and formed the subterranean lava flow because it had density approximately 2.5 times higher than the old pyroclasts.

Initially lava advanced in two major flows that quickly propagated toward the southwest and west. They have been named the Vodopadnoye and Leningradskoye flow fields after the two field huts buried by the lava (Fig. 4a). The Vodopadnoye flow field originated from the upper part of the eruptive fissure, and the Leningradskoye flow field mostly from the lower part. Both flows were of 'a'a type with average thicknesses of 2-5 m but thickening up to $15 \mathrm{~m}$ in the most distal areas (details of the 'a'a flow propagation mechanics are given in the next section). The lava flows quickly (ca. $200 \mathrm{~m} / \mathrm{h}$ ) advanced over terrain covered with snow from 0.1 to $0.5 \mathrm{~m}$ thick but locally up to $1 \mathrm{~m}$ thick. In most cases no meltwater was visible in front of the advancing lava; only a few small meltwater streams were observed locally. However, in some areas the quickly advancing flow fronts were completely enveloped in semi-translucent steam clouds that formed by vigorous boiling of meltwater at the lava flow/substrate boundary (Fig. 4d).
The first aerial photographic survey of the eruption was completed on 29 November 2012. At that time the flows covered an area of $14.46 \mathrm{~km}^{2}$, and the total erupted volume of lava was $0.072 \mathrm{~km}^{3}$ DRE. The average discharge rate of lava for the initial period of the eruption (27 November-1 December) was approximately $440 \mathrm{~m}^{3} / \mathrm{s}$ (Dvigalo et al., 2014).

Multiple vents located along the middle-upper parts of the eruption fissure (including the Menyailov vents) ceased to erupt by 1 December, 2012. Vents along the lowermost part of the fissure (on the summit of the Krasny cone and on its south-western foot) ceased to erupt by 8 December 2012. This event formally marks the end of the initial stage of the eruption. The front of Vodopadnoye flow field (that was fed by the middle-upper vents) stopped at an elevation of 705 masl. The flow was up to $10 \mathrm{~m}$ thick, $8.5 \mathrm{~km}$ long, and had a volume of $0.043 \mathrm{~km}^{3}$ DRE (Dvigalo et al., 2014). The Leningradskoye flow field fed by the erupting Naboko vents continued to grow very actively. By 8 December its length exceeded $10 \mathrm{~km}$ and the flow entered the forest at elevation 700 masl.

\subsection{The main stage}

After 8 December the fountaining and outpouring of lava continued only at an elevation of 1740 masl where the fissure made a turn $20^{\circ}$ toward the west. At that location a new scoria/agglutinate cone (the Naboko cone) started to grow; it remained active for the rest of the eruption (Fig. 6). During this main stage of the eruption the character of the activity became relatively monotonous but went through gradual transformations over the next 8 months (Fig. 3). 
a)

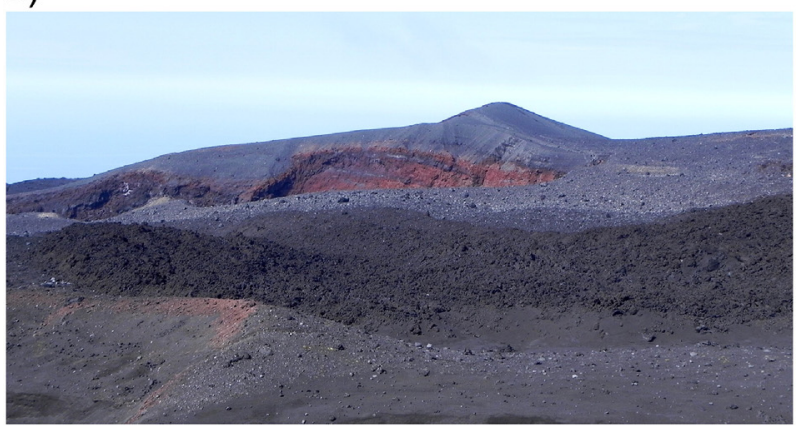

b)

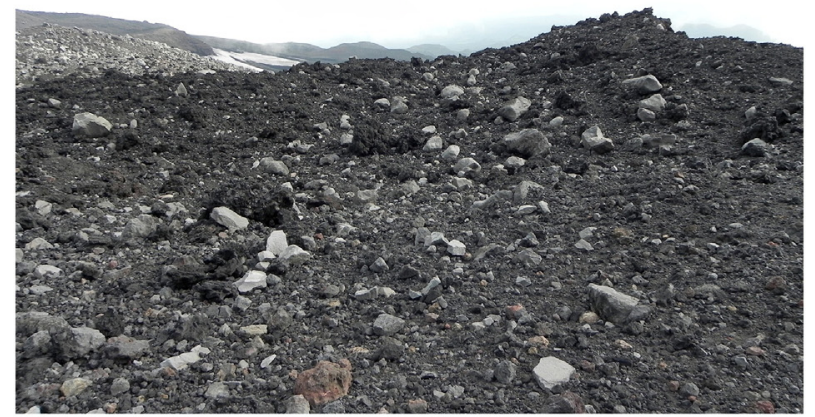

c)

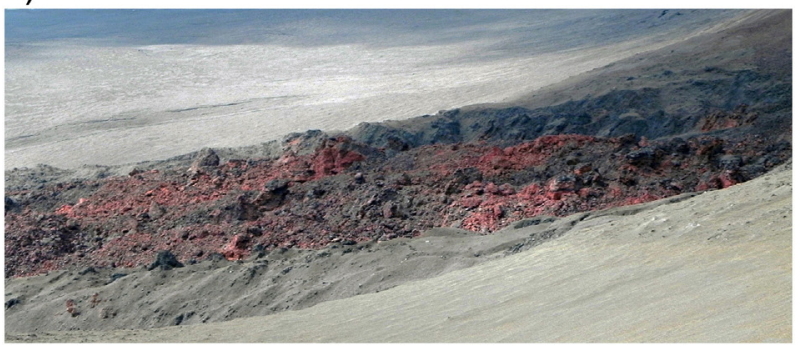

Fig. 5. Products of the initial stage of the 2012-13 eruption of Plosky Tolbachik; approximate locations of the images are indicated at Fig. 1. (a) General view of one of the explosive funnel-shaped craters of Menyailov group. The crater is excavated into agglutinate from older eruptions (lower brick-red vertical walls). Upper gray, layered pyroclastic apron (up to $10 \mathrm{~m}$ thick) formed during mostly phreatomagmatic explosions on 27 November-1 December 2012. In the foreground is an 'a'a lava flow originating from the upper part of the eruption fissure. (b) Close up view of the surface of the deposits in (a). Dark-gray juvenile bombs of cauliflower-type; light gray and brown non-juvenile blocks of country rocks. Individual rock fragments from the ballistic fallout are up to $1 \mathrm{~m}$ across. (c) Old pyroclastic deposits mobilized and transported by superficial sill/lava flow of the initial stage. Largest blocks of agglutinate are up to several meters across. All photos were taken in August 2014 by A. Belousov.

\subsubsection{Explosive activity}

Vigorous episodes of lava fountaining as well as short-lived outbursts caused by ruptures of large gas bubbles, occurred from the lava pond inside the main crater of the Naboko cone. Much less intense, sporadic outbursts occurred in one or two temporary satellite vents located on the outer southwestern slopes of the cone. In the main crater the outbursts occurred from several different or migrating locations in the pond of vigorously splashing, outgassing lava, which was spread across ca. $50 \mathrm{~m}$ of the floor of the crater (Fig. 6c). The outbursts ejected mostly large ( $\mathrm{dm}$ to $\mathrm{m}$ ) clots of very vesicular, low viscosity lava that continued to inflate while in the air and for some time after impacting the ground. Most of the ballistic fragments fell back into the lava pond while still molten. Others landed on the steep inner slopes of the crater and either rolled back into the lava pond or agglutinated to the crater walls; layers of the accumulated semi-liquid agglutinate periodically slid back into the lava pond where they were presumably disaggregated or remelted. Thus a significant volume of the lava pond was made from multirecycled, partly degassed basaltic melt. Only a few bombs were ejected far enough to be deposited on the outer slopes of the scoria cone; lapilli more frequently were deposited there. Most of the outbursts produced only minor volcanic ash, which was deposited at distances up to 10-20 km from the cone. However, several short explosive episodes produced more lapilli and ash than usual. The most prominent such episode was connected with formation of a new satellite vent on the southwestern slope of the scoria cone in the beginning of January.

The intensity of the explosive activity in the main crater fluctuated notably on timescales of hours to days. During periods of elevated activity, episodes of lava fountaining lasting tens of seconds were common. Periods of subdued activity were characterized by short-lived outbursts. Especially long and intensive periods of fountaining (up to $300 \mathrm{~m}$ high) occurred during the first two months of the eruption. These periods correspond to the times of the strongest seismic tremor (Fig. 3). Later fountaining episodes became rare, and short-lived outbursts up to $100 \mathrm{~m}$ high became increasingly common. The overall intensity of the explosive activity gradually declined during the course of the main eruption stage.

During the first month of the main stage (1 December-beginning of January), Naboko cone had two small satellite vents on its southwestern side that displayed weak explosive activity; these vents were not active for very long and thus were not investigated. In January ash explosions on the southwestern outer slope of Naboko cone marked the formation of the new, relatively large satellite vent that stayed active until the eruption ended (Fig. 6a and b). The satellite vent was a pit-like crater approximately $30 \mathrm{~m}$ in diameter and $30 \mathrm{~m}$ deep. A small (15 $\mathrm{m}$ across), persistent lava pond formed on the floor of the crater. The explosive activity in the satellite vent was similar in general to that of the main crater but of much weaker intensity, with small lava fountains and shortlived outbursts through the lava pond. From a distance, a pulsating red glow was usually visible above the satellite crater, with only an occasional ejection producing bombs visible from a distance.

Until late December the growing Naboko cone had a horseshoe shape due to the intense outpouring of lava, which carried away the accumulating fallout of scoria deposits on its southern sector. In the beginning of January the discharge of lava notably decreased and the ejected scoria started to accumulate in the former breach area, gradually building the southern crater wall. By the end of the eruption the former breach was almost completely filled by agglutinate and scoria deposits.

\subsubsection{Lava ponds}

The lava pond in the main crater changed notably throughout the course of the eruption. Initially the pond opened broadly southward, where lava freely poured out through the breach in the scoria cone. During explosive outbursts, large waves were generated on the surface of the lava pond and surged lava out of it. After the breach in the cone was filled by scoria, the lava pond developed an oval shape elongated approximately in the direction of the eruption fissure, with short $(25 \mathrm{~m})$ and long $(50 \mathrm{~m})$ axes (Fig. $6 \mathrm{a}$ and $\mathrm{c}$ ). By the end of the main stage of the eruption, the average level as well as surface area of the pond started to decrease. In July-August the oval pond parted into two small circular ponds (each $\sim 10 \mathrm{~m}$ across) that had different levels of lava (of the order of $5 \mathrm{~m}$ ). During explosive outbursts lava from the upper pond spilled over into the lower pond. The level of lava was so low during several periods in the second half of August that its surface was not visible from the crater rim.

A small lava pond in the pit crater of the satellite vent was poorly observed but apparently changed little during the course of the main stage. 
a)

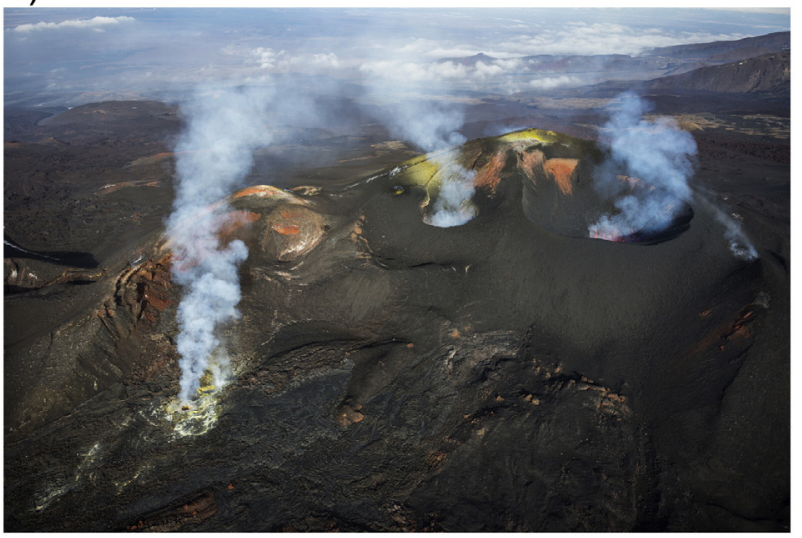

c)

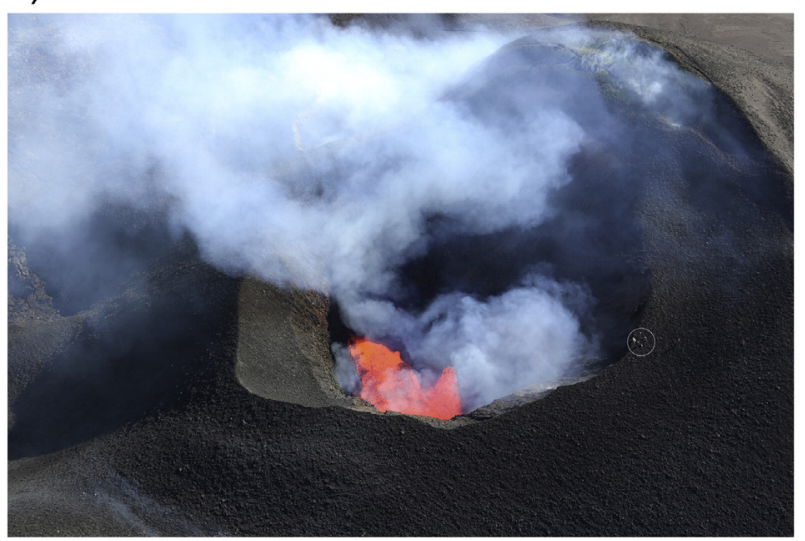

b)

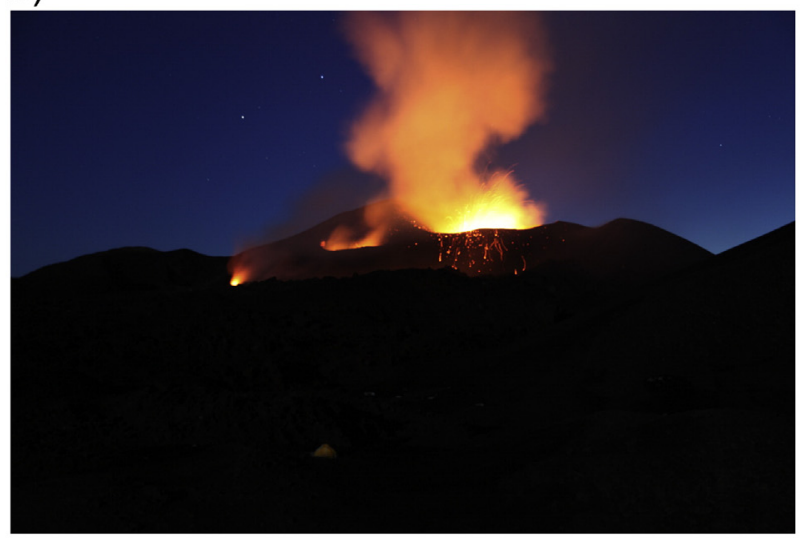

d)

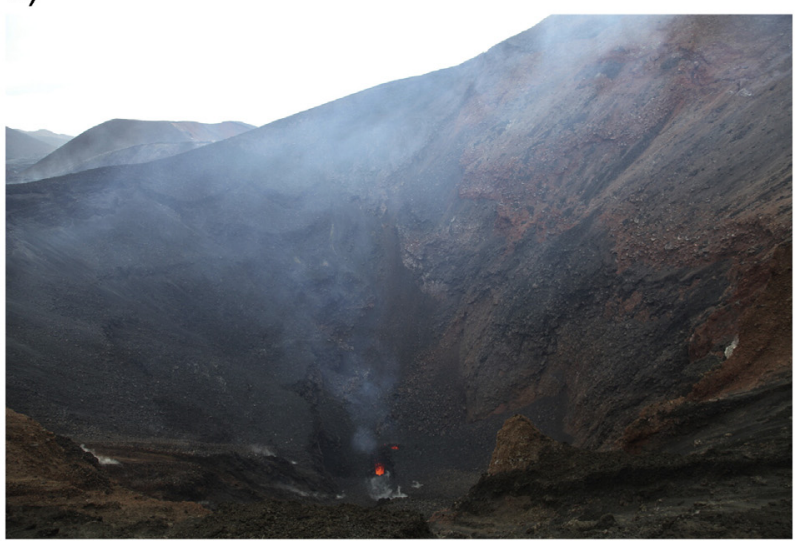

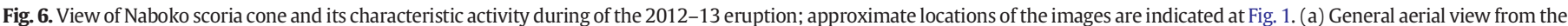

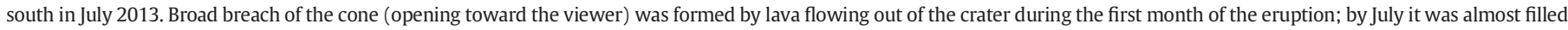

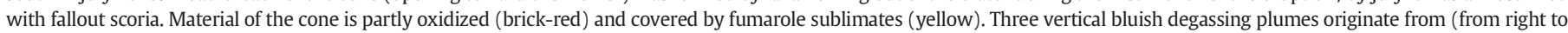

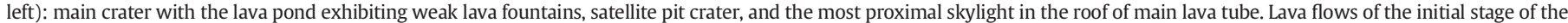

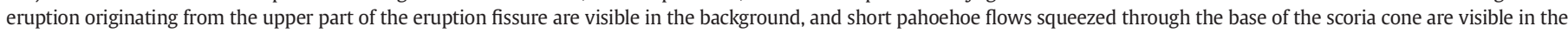

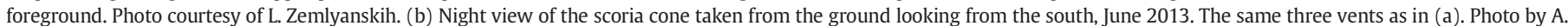

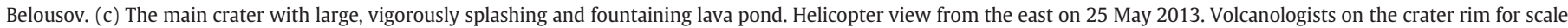

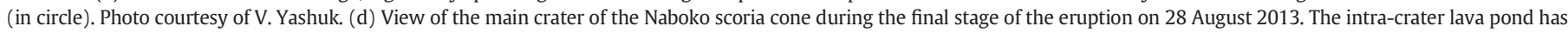
drained, and weak Strombolian-type explosive activity occurs from two small vents on the crater floor. Photo by A. Belousov.

\subsubsection{Lava effusion}

The discharge of lava during the main stage of the eruption gradually declined with time from $\sim 100$ to $10-20 \mathrm{~m}^{3} / \mathrm{s}$ by visual estimates; photogrammetric data from aerial photography indicate a decrease from 140 to $18 \mathrm{~m}^{3} / \mathrm{s}$ (Dvigalo et al., 2014). It was accompanied by changes in both the prevailing type of propagation of lava flows and their areal distribution (Figs. 3 and 7).

Initially, when average discharge was relatively high, lava poured out directly from the intra-crater pond through the wide breach on the southern side of the horseshoe-shaped Naboko cone. Downslope the flowing lava traveled through a deep and relatively narrow (5-10 $\mathrm{m}$ across) open channel in partly agglutinated scoria deposits (both ancient and new scoria cone material carried out by the lava). The channel had rather stable banks armored by layers of solidified lava formed by fluctuations of lava level and frequent overflows. The velocity of lava flow in the channel was $2-3 \mathrm{~m} / \mathrm{s}$. In the beginning of January the discharge decreased to $\sim 50 \mathrm{~m}^{3} / \mathrm{s}$, and the upper part of the outflow channel (proximal to the lava pond) transformed into a short lava tube. After that, lava was transported from the lava pond(s) through the subterranean tube(s) that opened on the ground surface at some distance from the scoria cone (small volumes of pahoehoe lava continued to extrude episodically through the southern foot of the Naboko scoria cone throughout the main stage of the eruption). Post-eruption mapping of the proximal lava tube shows that it has an average diameter of $10 \mathrm{~m}$, with a gradient of $3-5^{\circ}$.

Farther down slope, the transport of lava continued initially in a rather stable open channel, then in the form of a branching lava river bounded by low banks of stagnated lava clinker, and finally in a rolling caterpillar-track motion at the leading parts of 'a'a-type flows (Fig. 7a and $\mathrm{b}$ ). Advance rates for 'a'a flows were up to $1 \mathrm{~m} / \mathrm{min}$.

Lava flowing out of the tube immediately developed a flexible, frothy surface layer 5 to $10 \mathrm{~cm}$ thick having notably higher viscosity (due to surface outgassing and cooling) than the underlying lava (Fig. 7c). From time to time large (up to $1 \mathrm{~m}$ across) bubbles of gas slowly bulged up and punctured the surface layer of lava. The surface layer underwent complex multiple deformations depending on the lava flow dynamics: it was folded into various ropy structures and/or ripped into pieces that experienced rotations and collisions; many of these pieces were repeatedly agglutinated together and then split apart. During transport the material of the surface layer gradually oxidized, solidified, and eventually formed a lava clinker (coarse autobreccia composed of scoriaceous, partly oxidized chunks of lava). The clinker had a lower density (because of higher vesicularity) than the lava and floated on its surface. The temperature of the clinker was only few degrees less than that of the lava below; however the clinker did not remelt even after being enveloped in fresh lava. The process of clinker formation was most 
a)

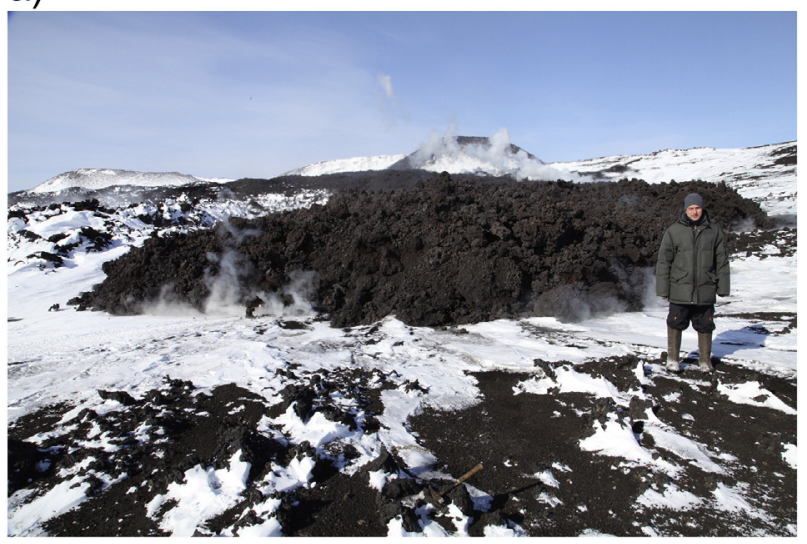

c)

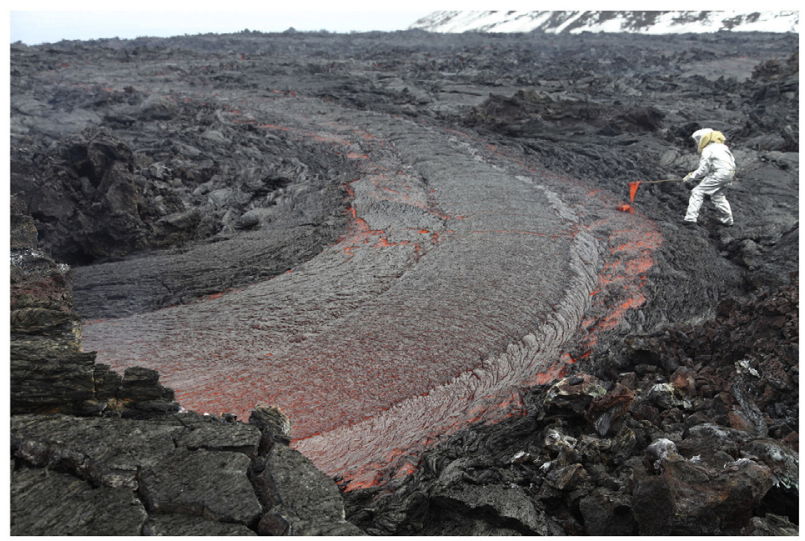

e)

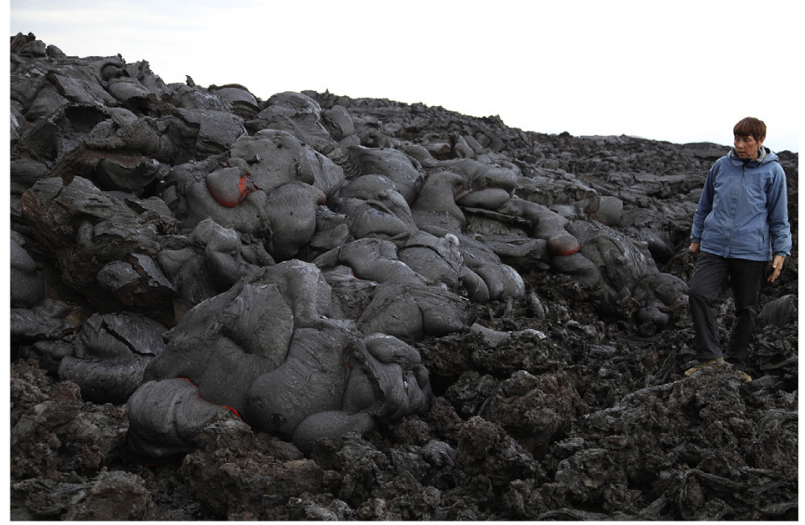

b)

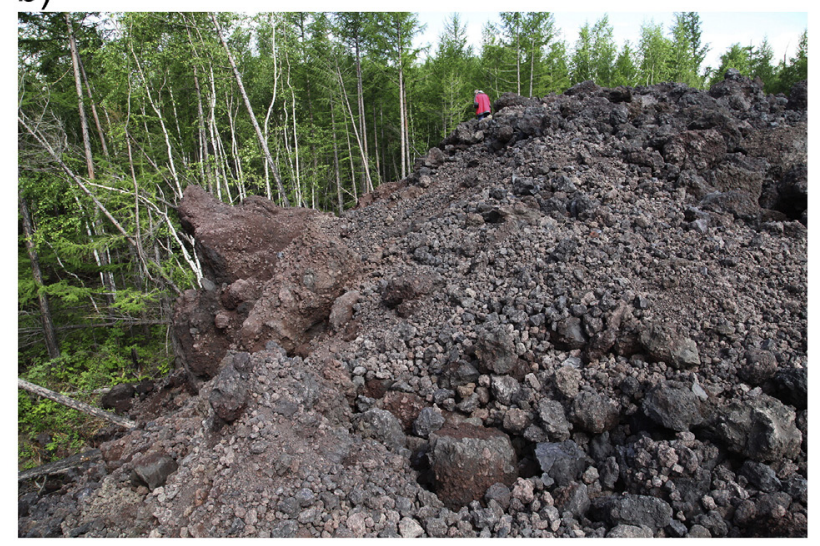

d)

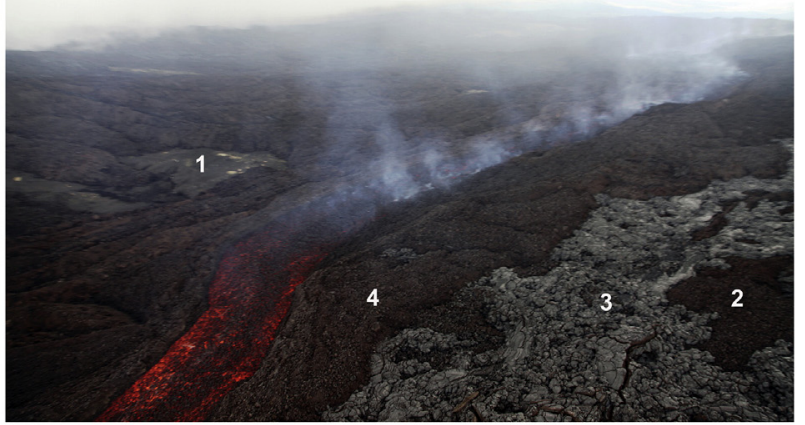

f)

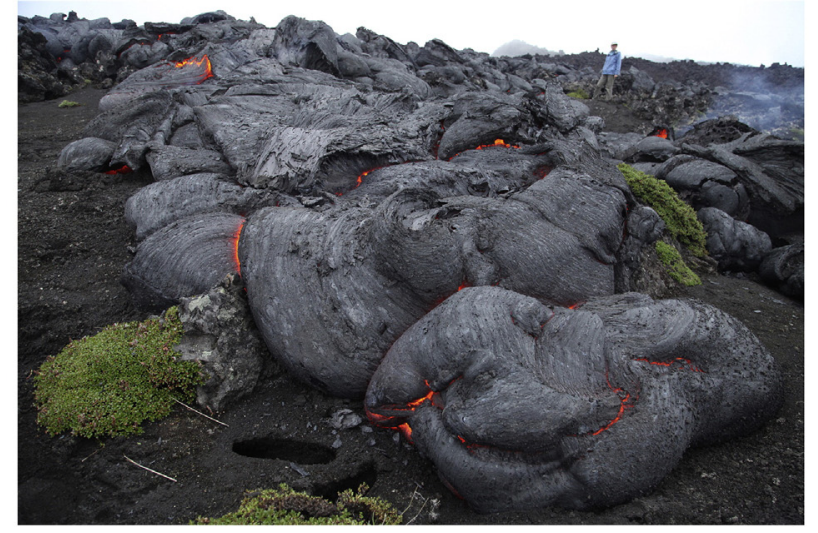

Fig. 7. Lava flows produced during the 2012-13 eruption; approximate locations of the images are indicated at Fig. 1. (a) Actively advancing lobe of 'a'a lava in the Toludskoye lava field, March 2013. Note absence of meltwater streams in front of the lava. (b) Front of one of the longest and thickest $(15 \mathrm{~m})$ 'a'a lava flows in the distal area of Leningradskoye lava field emplaced in December 2012. Picture was taken in August 2013. (c) Lava river coming out of a lava tube at approximately $1 \mathrm{~km}$ distance from the Naboko cone, March 2013. The surface layer of lava with ropy texture was not preserved in the final deposit; upon transportation it was deformed, oxidized and turned into clinkery breccia of 'a'a. Sampling of lava routinely performed during the eruption course allowed tracking of compositional changes with time (see Volynets et al., 2015). (d) Lava river in the Toludskoye lava field that is about $7 \mathrm{~m}$ wide at $4 \mathrm{~km}$ distance from the active scoria cone. Aerial view on 3 June 2013. Sudden breakout of the main lava tube formed this lava river with high discharge rate that resulted in formation of a large 'a'a lava flow ('a'a flows were otherwise rare by this time). Four surfaces of different depositional ages are visible: 1 - pre-eruption kipuka, 2 - initial 'a'a lava deposited in April 2013; 3 - pahoehoe lava deposited in May 2013; 4 - fresh 'a'a lava deposited by this lava river. (e) and (f) Front of pahoehoe flow within the Toludskoye lava field; in (e) the June 2013 flow is advancing over the previously deposited 'a'a flow, and in (f) the July 2013 flow is advancing over the 1975-76 scoria fallout deposits. All photos are by A. Belousov.

active along lateral margins of the lava channel, where the surface layer of lava experienced the strongest deformation. Chunks of the clinker tended to accumulate along lateral margins of the lava channel. At first small separate clinker rafts were formed; then these rafts grew in size and combined into continuous lateral bands of moving clinker, which moved slower than the parent flow. Locally the moving clinker stagnated along the banks of the lava river, but with distance from the source the lateral bands of clinker became broader and finally occupied the entire surface of the lava flow.

When a lava flow exited the stable channel, it propagated as a broad sheet tens to hundreds of meters wide bounded by low banks composed of stagnated clinker. Commonly the lava river formed several meandering and splitting or merging branches. At lower elevations these branches formed individual 'a'a lobes (Fig. 7a). The lobes were hundreds 
to thousands of meters long, and tens of meters wide, with average estimated thicknesses of 2-4 $\mathrm{m}$ but up to $6.5 \mathrm{~m}$ locally. The flow fronts were characterized by a rolling caterpillar-track motion where a friable layer of clinkery autobreccia composed of $\mathrm{cm}$ - to dm-sized clasts was transported on top of a moving molten lava core. At the frontal part of the advancing flow, the breccia continuously rolled off the flow upper surface and then was overridden by the core of the flow to produce the basal breccia. After the passage of the leading lava front, the flow developed well-defined lateral levees composed of the clinkery breccia. Temperatures of the incandescent lava core (exposed in frontal parts of the 'a'a flows) were between $980^{\circ} \mathrm{C}$ (FLIR) and $1055^{\circ} \mathrm{C}$ (Type $\mathrm{K}$ thermal probe; Edwards et al., 2014). Temperatures of autobreccia blocks that had rolled off of the lava front were $900{ }^{\circ} \mathrm{C}$ (FLIR).

A propagation style similar to that of the 'a'a flows was also common for the short-lived (hours) sheet flows of fluid lava that formed as a result of voluminous spillovers from dammed lava channels and tube skylights. The spillovers had thin elastic outer "skin" that was able to roll like a caterpillar-track without breaking into pieces, and thus they had no upper or basal breccias. The flows were broad (up to $100 \mathrm{~m}$ ), thin $(<0.5-1 \mathrm{~m})$ lava sheets that propagated with velocities up to 1-2 m/s. Lava morphologies intermediate between the sheet and 'a'a flows (e.g., platy pahoehoe) were also observed.

As the discharge of lava gradually declined, the lava tube(s) became longer and developed complex branching; from time to time some branches were plugged by solidified lava and new ones appeared. In the end of January, the main lava tube was $700 \mathrm{~m}$ long, in April $1.5 \mathrm{~km}$ long, and in June $2-3 \mathrm{~km}$ long. By the final stage of the eruption a complex system of lava tubes up to $5 \mathrm{~km}$ long had developed. The diameters of individual tubes varied from 1 to $10 \mathrm{~m}$, and were located at different depths (1-20 m) from the ground surface; sometimes multiple tubes at different levels within the flow thickness were active.

Important structural elements of the lava tubes were openings in their roofs (skylights) through which continuous degassing and periodic spillovers of lava occurred. In January the first short lava tube had no skylights. In February the length of the lava tube exceeded $1 \mathrm{~km}$ and the first skylights $2-3 \mathrm{~m}$ in diameter were formed at distances $300-500 \mathrm{~m}$ from the base of the scoria cone (Fig. $6 a$ and b). Later these skylights were enlarged up to $15 \mathrm{~m}$ in diameter and 10-20 m deep by roof collapses. By June, multiple small skylights had formed all over the proximal-middle area of Toludskoye lava field. Undiluted volcanic gases with temperatures up to $1080^{\circ} \mathrm{C}$ vigorously emanated from the skylights proximal to the scoria cone (Zelenski et al., 2014). The distal skylights discharged incandescent gases that were strongly diluted by air. The skylights were clearly visible on satellite/aerial infrared images of the lava field as small dots having temperatures much higher than the surrounding surfaces. Most of the skylights were associated with shatter rings and tumuli that were formed due to fluctuations of "magmastatic" pressure in the tubes; these fluctuations mostly occurred during blockages of the tubes by accretionary lava balls, roof collapses, or solidification of lava. During the blockage episodes, lava commonly poured out from the skylights located upstream.

During the last months of the main stage (in June-August 2013), lava was transported mostly inside the lava flow field through the complex system of multiple branching tubes. Fluid melt appeared on the ground surface mostly at the frontal parts of the lava flows, which were emplaced by "inflation" style as pahoehoe flows (Fig. 7e and f). Short-lived open lava rivers and corresponding 'a'a flows appeared only during ruptures of the large tubes that locally yielded high discharges of lava (Fig. 7d). The pahoehoe flows propagated through sequential extrusion and inflation of multiple, individual, dm-sized, smooth-surfaced, bulbous lava lobes. Each lobe slowly inflated to maximum dimensions of approximately $1 \mathrm{~m}$ before fracturing to produce a new lobe, commonly growing in a direction oblique/perpendicular to the parental lobe. Subsequently the whole system of interconnected lobes continued to inflate slowly to add to the flow volume. The advance rates for pahoehoe lava flows were on the order of $0.05 \mathrm{~m} / \mathrm{min}$.
Temperatures of the incandescent lava inside lobes were up to $1080^{\circ} \mathrm{C}$ (Type K thermal probe; Edwards et al., 2014), and temperatures of the lava lobe surfaces were up to $1000{ }^{\circ} \mathrm{C}$ (FLIR). The individual lobes were somewhat larger and more spherical than those of typical Hawaiian pahoehoe lobes, possibly due to higher lava viscosity that was of the order of $10^{3}-10^{4} \mathrm{~Pa} \cdot \mathrm{S}$ (measured in the field with a penetrometer). More spherical lobes with thick chilled crust, similar in appearance to submarine pillow lavas, were found during winter months (JanuaryApril) and flattened lobes similar to 'entrail' pahoehoe were common in the summer (May-August).

During the winter period ( $>4$ months in total), the lava flow fronts frequently advanced over snow fields ranging in thickness from 0 to $5 \mathrm{~m}$ (commonly $0.5-2 \mathrm{~m}$ ). The character of the lava-snow interaction depended in each particular case mostly on the emplacement style of the lava flow. The 'a'a flows and spillovers of fluid lava, both of which advanced in a rolling caterpillar-track motion, commonly propagated over the snow. The pahoehoe flows advancing through sequential extrusion and inflation of multiple individual lava lobes propagated under/inside the snow. Little meltwater was formed in all cases; no substantial lahars were observed during the entire eruption. Secondary phreatomagmatic explosions on the flows were rather weak and rare. Edwards et al. $(2014,2015)$ describe the details of the lava-snow interaction processes.

Dvigalo et al. (2014) analyzed the aerial distribution of the lava flows. The Leningradskoye lava field reached its maximum length of $17.8 \mathrm{~km}$ by 13 December 2012; the lava flow front stopped at an elevation of 290 masl. That time the field had an area of $17.04 \mathrm{~km}^{2}$ and a volume of $0.208 \mathrm{~km}^{3}$. After that the flow started to widen and thicken, and it turned into a compound lava flow. The lava field continued to grow until April and reached an area of $22.44 \mathrm{~km}^{2}$ and volume $0.397 \mathrm{~km}^{3}$. Starting from January more and more lava lobes started to move toward the south, southeast, and east, and the third lava field, referred to as 'Toludskoye', started to form. The Toludskoye lava field continued to grow until the end of the main stage of the eruption in late August. The Leningradskoye and Toludskoye lava fields were initially built of multiple individual lobes of classic 'a'a, probably because of the high discharge rates of lava during the first months of the main stage. During that time, pahoehoe surfaces (mostly of ropy morphology) were formed only locally where lava spilled from the blocked lava channels or poured out of the skylights in lava tubes. Once the overall lava discharge began to decrease starting in February, pahoehoe lobes started to become more common. In many cases short pahoehoe flows of toothpaste and/or entrail type squeezed through lateral and upper surfaces of active or recently formed 'a'a flows. Such flows make up approximately $10 \%$ of the area of the Leningradskoye lava field and $70 \%$ of the area of the Toludskoye lava field. The maximum thickness of lava was accumulated in the northern part of the Toludskoye field where it reached $70 \mathrm{~m}$. By 5 June the frontal part of the Toludskoye lava field descended to altitudes of 1100 masl (Dvigalo et al., 2014). The field was $4260 \mathrm{~m}$ long, had an area of $6.6 \mathrm{~km}^{2}$, and volume of $0.08 \mathrm{~km}^{3}\left(0.07 \mathrm{~km}^{3}\right.$ DRE). This volume did not increase notably by the end of lava effusion in the end of August.

\subsection{The final stage}

On 23 August, lava discharge abruptly decreased from $10-20 \mathrm{~m}^{3} / \mathrm{s}$ to zero and lava ceased flowing through the system of lava tubes. Through the skylights, which continued to emanate gases with temperatures about $1000{ }^{\circ} \mathrm{C}$, the orange-red incandescent interiors of the empty lava tubes were visible. This event, accompanied by a marked decrease of seismic tremor to below detection levels (Fig. 3), formally divides the main and final stages of the eruption.

Simultaneously lava drained completely from the lava ponds in the main crater and the satellite vent of Naboko cone. The satellite vent stopped erupting, while on the bowl-shaped bottom of the main crater 2-3 small (3-5 m across) Strombolian-type vents continued to eject 
lava lumps to heights up to $30 \mathrm{~m}$ with periodicity of 1-10 s (Fig. 6d). These outbursts, as well as several slight subsidence episodes of the vent area, indicated that the magma column was still at a shallow depth below the crater floor. The ejected lava bombs accumulated around the vents to form a small intra-crater spatter cone. Such activity lasted several days, but by the end of the first week of September surface activity ceased completely. By the end of the eruption the Naboko cone reached a height of $125 \mathrm{~m}$. The main crater had a diameter of $\sim 100 \mathrm{~m}$ and a depth of $\sim 30 \mathrm{~m}$.

\section{Eruption products}

Lava flows of the eruption are described in the previous sections. Here we provide more details about the magma composition, briefly describe pyroclastic deposits of the eruption and summarize data on the total volumes of the erupted products.

\subsection{Composition}

Lava flows and pyroclasts from the eruption were routinely sampled by the monitoring teams and studied in detail by Volynets et al. (2013, 2015). The erupted magmas are high-Al basaltic trachyandesites of two varieties (Fig. 2) with somewhat different concentrations of $\mathrm{SiO}_{2}$ (on average 55 versus 52 wt.\%), $\mathrm{Na}_{2} \mathrm{O}+\mathrm{K}_{2} \mathrm{O}$ (on average 6.5 versus 6 wt.\%) and $\mathrm{FeO}$ (on average 9 versus 11 wt.\%). Mineralogically both magmas are subaphyric with rare phenocrysts of plagioclase, olivine and microphenocrysts of plagioclase, olivine, pyroxene and magnetite.

The more silica- and alkali-rich batch of magma was erupted during the initial stage of the eruption, mostly from the upper part of the eruptive fissure (including the Menyailov vents). The volume of this first batch of magma was of the order of $0.1 \mathrm{~km}^{3}$ (DRE). The batch has the highest alkali and silica content ever found at Tolbachik.

Magma with less silica, slightly less alkalis, and more Mg, Ti, and Fe started to erupt on 28 November 2012 from the lower part of the eruptive fissure (the Naboko vents). During the first two weeks of December the composition of products from the Naboko vents gradually changed to more mafic, and it remained constant from the middle of December to the end of the eruption. The volume of this main batch of magma was about $0.45 \mathrm{~km}^{3}$ (DRE).

The changes in chemical compositions during the 2012-13 eruption can be explained by fractionation at low pressures (100-300 MPa), corresponding to a shallow magma storage area at depths of $3-10 \mathrm{~km}$ (Volynets et al., 2015). The variation during the course of the eruption is consistent with a tapping of magma storage zone where magma is not strongly chemically zoned, but also is not being thoroughly chemically homogenized. Composition of the main stage of the 2012-13 magma is similar to that erupted from the 1975-76 Southern Breakthrough in silica and $\mathrm{Mg}$, higher in alkalis and $\mathrm{Ti}$, and lower in $\mathrm{Ca}$ and Al (Fig. 2).

\subsection{Pyroclasts of the initial stage}

Low-profile aprons of coarse-grained pyroclasts surround multiple explosive funnel-shaped vents formed during the initial explosive activity of the eruption (Fig. 5). The aprons comprise a poorly sorted, crudely layered mixture of juvenile bombs of cauliflower type, angular blocks of country rocks (mostly red and black scoria, few dense lavas), and lapilli of the same components. At different vents the maximum thickness of the deposit ranges from several centimeters to several (up to 10) meters. We interpret the deposit as phreatomagmatic, having formed by contact of rising magma with ground water or permafrost; it corresponds to the lower layer of distal ash deposited near the KlyuchiKozyrevsk road overnight on 27-28 November 2012 (see Fig. 4 of Senyukov et al., 2015).

The phreatomagmatic deposit around some of the explosive vents is covered by a layer of bombs and lapilli comprising vesicular juvenile basalt. The layer had different maximum thickness around different vents - from individual scattered bombs to a layer about $1 \mathrm{~m}$ thick; it interpreted to be of magmatic origin, formed by lava fountaining. The deposit corresponds to the upper layer of distal ash deposited in the area of the Klyuchi-Kozyrevsk road overnight on 27-28 November 2012 (see Fig. 4 of Senyukov et al., 2015). Characteristics of this deposit are similar to those of the pyroclastic deposits of the main and final stages (see below)

\subsection{Pyroclasts of the main and final stages}

Morphologies of the ejected pyroclasts were relatively uniform throughout the course of the main eruption stage (Fig. 8). Most of the bombs are irregular lumps of light-weight, vesicular basaltic scoria flattened by landing impacts. Some of the bombs have more elongated, ribbon-like shapes, but a few are relatively equidimensional. Extensive post-ejection vesiculation and inflation formed large gas bubbles inside some bombs; a few even have a hollow core. The tephra deposit is characterized by a complete absence of xenoliths. Most of the ejected lapilli and ash particles are irregular, spiky fragments of scoria (Fig. 8c). Some pieces resemble rough reticulite and thick Pele's hair. The pyroclastic material continued to be highly vesicular until the very end of the eruption, indicating no notable decrease in the gas content of the magma.

For about one week in early January, the main crater of Naboko scoria cone ejected pyroclasts of notably lower vesicularity. Observations indicate that at that time the intra-crater lava pond developed a large embayment filled with notably degassed melt. In the embayment, large (several meters across), spherical gas bubbles periodically surfaced, quickly expanded and burst, ejecting a broad fan of lumps of the degassed melt. The resultant pyroclasts were notably denser than those ejected simultaneously from the other parts of the lava pond.

Together with the scoriaceous lapilli, crystal lapilli of plagioclase up to $2 \mathrm{~cm}$ in diameter also were ejected (Fig. 8d). Although rare in general, in some areas these crystals were deposited in abundance where they were concentrated by the processes of atmospheric and aeolian sorting. The size and abundance of the crystal lapilli of the 2012-13 eruption are notably smaller than those of the 1975-76 Southern Breakthrough which ejected lapilli up to $3.5 \mathrm{~cm}$ in maximum dimension.

\subsection{Volumes of the erupted products}

Precise volumes of the erupted products for different periods of the 2012-13 eruption were determined by photogrammetric methods basing on the data from several aerial surveys (Dvigalo et al., 2014). Unfortunately, the latest aerial photogrammetric survey was completed 3 months before the end of the eruption on June 5, 2013. Thus, to estimate the final volume of the erupted lava flows, we extrapolated data taken from Fig. 3. The total volume of the erupted lava flows reached $0.52 \mathrm{~km}^{3}\left(0.46 \mathrm{~km}^{3} \mathrm{DRE}\right)$ by 5 June, and probably reached $\sim 0.6 \mathrm{~km}^{3}\left(0.54 \mathrm{~km}^{3} \mathrm{DRE}\right)$ by the end of the eruption in September 2013 (Table 1).

We assume that final volumes of the erupted pyroclasts did not change much after the latest aerial photogrammetric survey on 5 June 2013. The erupted volume of pyroclasts includes Naboko cone $\left(\sim 0.02 \mathrm{~km}^{3}\right.$ of scoria $\left.=0.008 \mathrm{~km}^{3} \mathrm{DRE}\right)$, small volumes of pyroclastic material deposited along other parts of the eruptive fissure, including the Menyailov vents $\left(\sim 0.0004 \mathrm{~km}^{3}\right.$ of scoria $\left.=0.00015 \mathrm{~km}^{3} \mathrm{DRE}\right)$, and an unknown, rather small volume of distal ashes. Taken together these data indicate that total volume of the erupted pyroclasts probably comprises $\sim 0.01 \mathrm{~km}^{3}$ DRE. Thus, we estimate the total volume of erupted magma during the 2012-13 eruption (lava + pyroclasts) as $\sim 0.55 \mathrm{~km}^{3}$ DRE (Table 1). 
a)

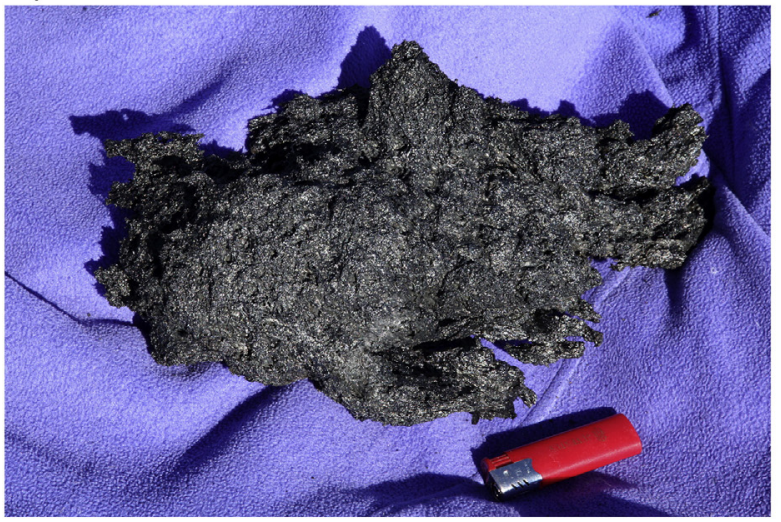

c)

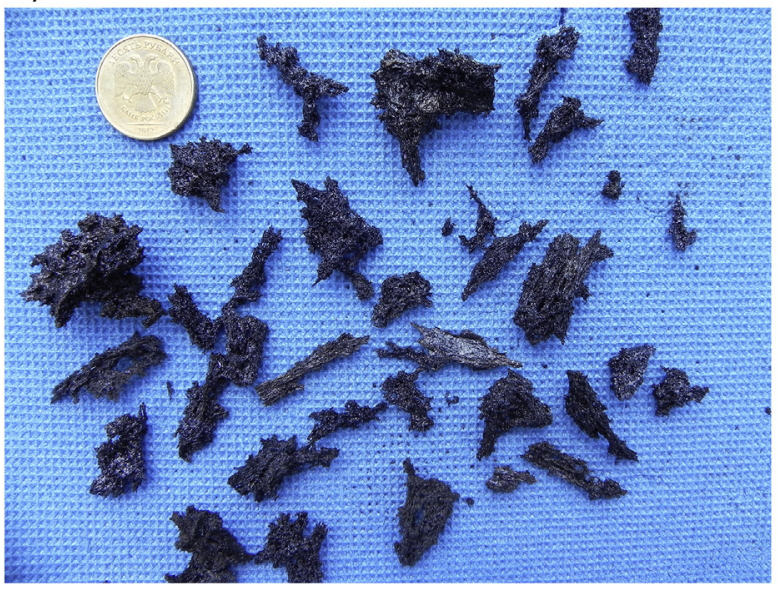

b)

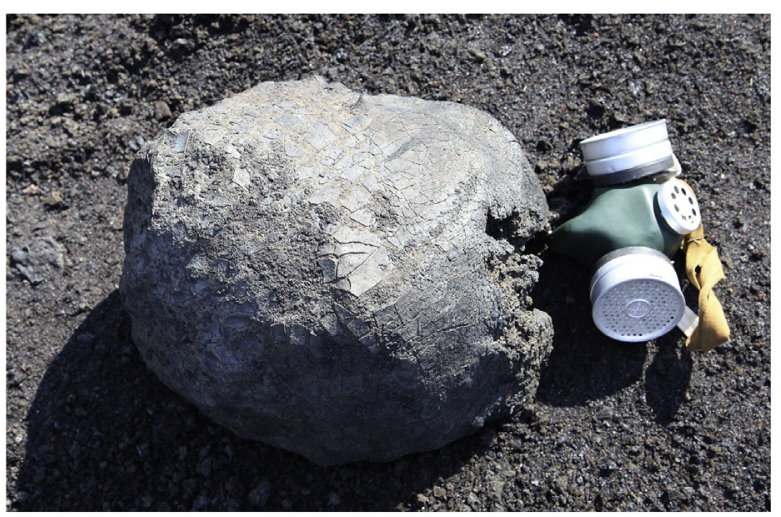

d)

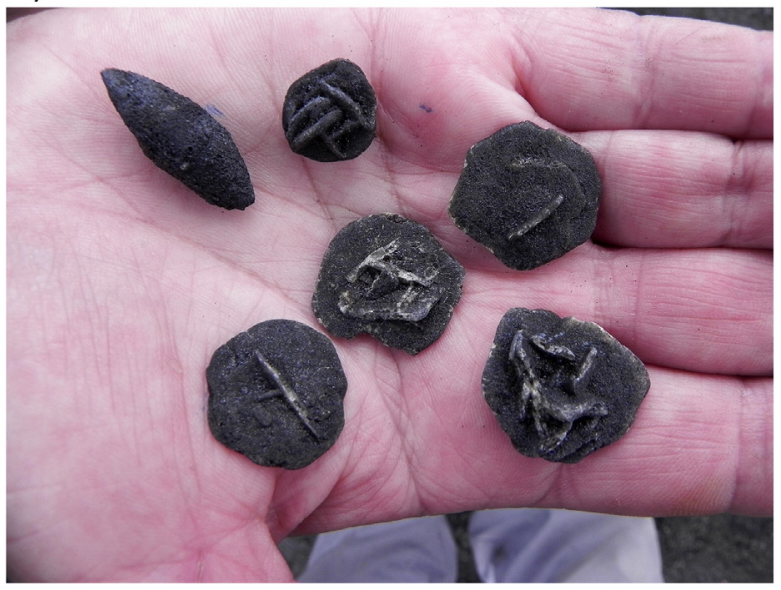

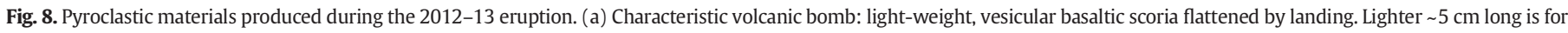

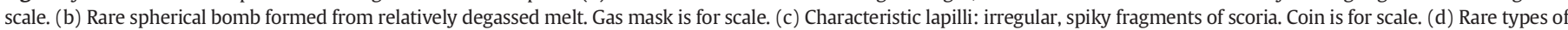

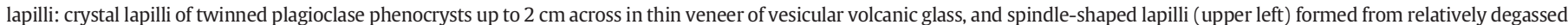
melt. All photos are by A. Belousov.

\section{Discussion}

The magma composition and style of the 2012-13 eruption of Tolbachik were in many aspects similar to those of the Southern Breakthrough in the 1975-76 eruption: voluminous long-term outpouring of fluid lava with gradually declining discharge, and the accompanying rather mild Hawaiian-Strombolian explosive activity in the crater of the growing scoria cone. The erupted volumes of magma are comparable: 0.55 and $0.87 \mathrm{~km}^{3}$ DRE respectively (Table 1 ). However, several features of the 2012-13 eruption were different: (1) the discharge rate of lava, especially during the initial stage, was higher; (2) the relative proportion of 'a'a to pahoehoe was notably higher; (3) lava tubes were longer and of larger diameter; (4) the erupted products were almost aphyric, containing only a few plagioclase phenocrysts of smaller size; and (5) no simultaneous caldera subsidence occurred at the volcano summit. On the other hand, the dynamics of both eruptions, which involved high-Al magma, differed from those of historical eruptions of high-Mg magma: the 1941 and 1975-76 Northern Breakthrough were relatively short-lived and more explosive (SubplinianUltrastrombolian). The reasons for these differences can be explained if the magma transport and storage system of the volcano and its functional mechanisms are understood.

After the 1975-76 eruption it was widely accepted that the rifts of Tolbachik represent a separate volcanic structure with its own magma transport and storage system independent of the feeding system of the stratovolcano Plosky Tolbachik (e.g., Flerov et al., 1984; Fedotov et al., 1991). Later Fedotov et al. (2010) proposed the existence of an integrated magma transport system for the stratovolcano and the rifts where high-Mg and high-Al magmas ascend to the ground surface along different paths from different magma storage zones that are interconnected at depth. Comparison of the characteristics of the precursory seismicity and the sequences of the eruptive events in 1975-76 and in 2012-2013 (Tokarev, 1978; Saltykov et al., 2012; Kugaenko et al., 2015; Senyukov et al., 2015), combined with the new geological and petrological data (Churikova et al., 2015; Portnyagin et al., 2015; Volynets et al., 2015), allow us to formulate a revised functional model for the magma transport and storage system of Tolbachik (Fig. 9) that builds upon the model of Fedotov et al. (2010).

\subsection{A functional model for Plosky Tolbachik Volcano}

The volcanic system, comprising the stratovolcano Plosky Tolbachik and its two radial volcanic rifts, since 2000 years ago produces alternating eruptions of two genetically related magma types: high-Al basalt (eruptions at the summit and along both rift zones) and high-Mg basalt (eruptions only along the southwest rift).

Locations and orientations of the volcano's central conduit and the northeastern and southwest rifts are probably controlled by deep regional fault (Fig. 9) that dissects the volcanic basement (Melekestsev et al., 1970; Ermakov et al., 2014). Major northeast-trending faults are common in the Central Kamchatka Depression. For example, they are clearly visible on the flat surface of the lava plateau in the south part of Hapichenskaya Depression $35 \mathrm{~km}$ east of Tolbachik, where they are not covered by young volcanic deposits and thus are well expressed in 

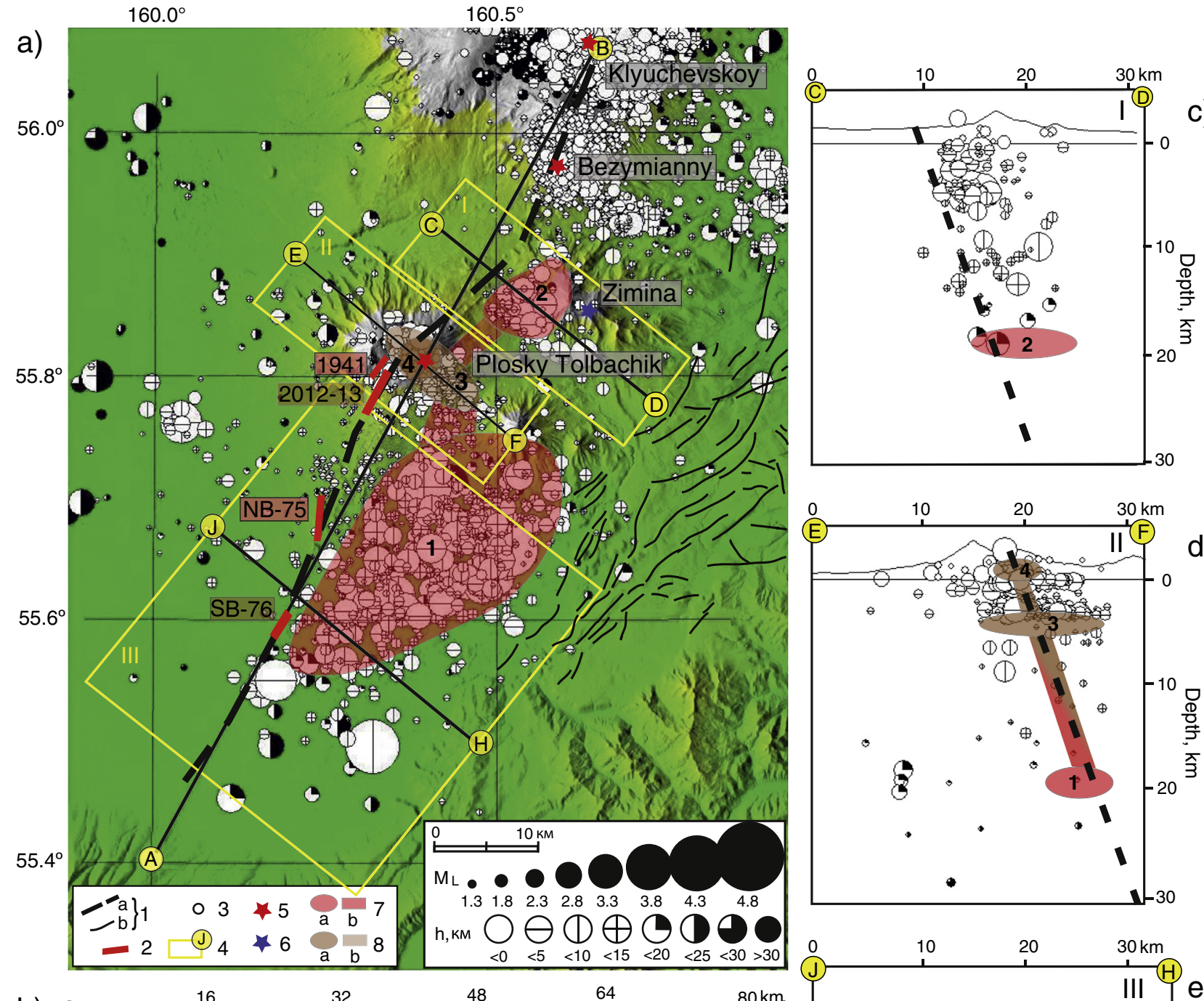

c)
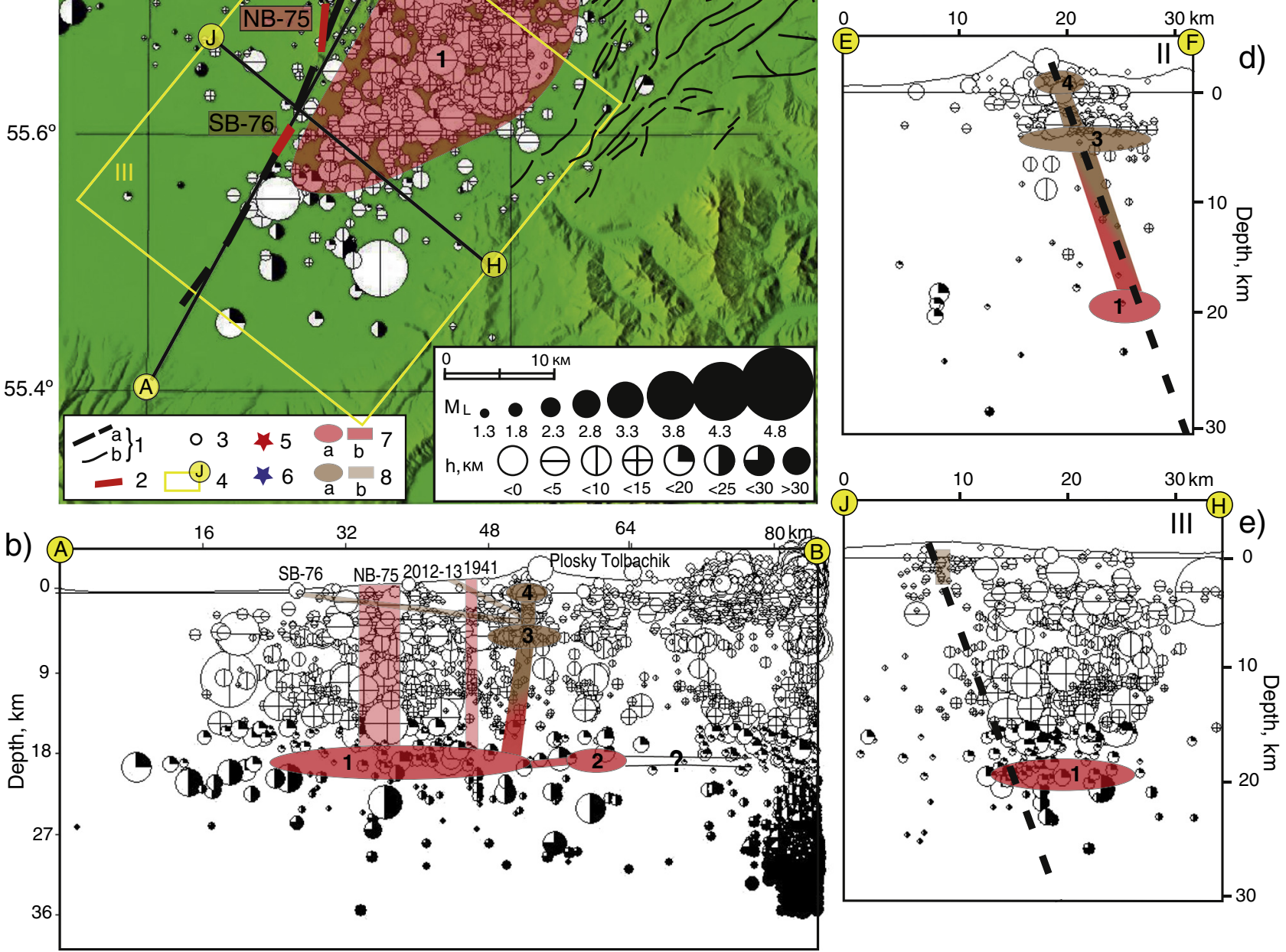

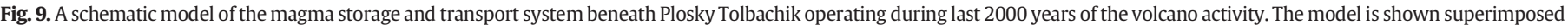

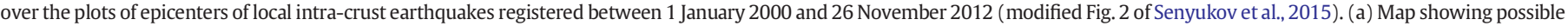

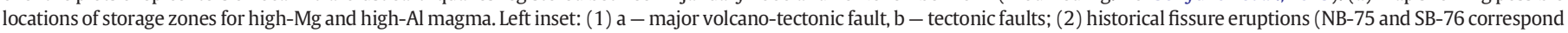

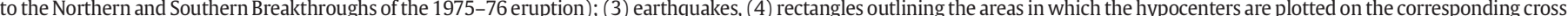

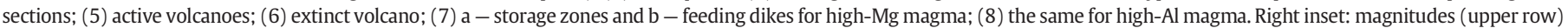

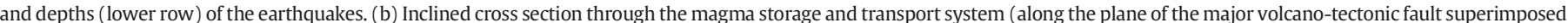

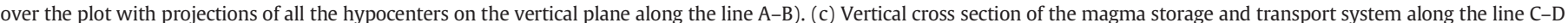

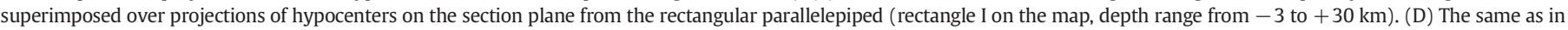

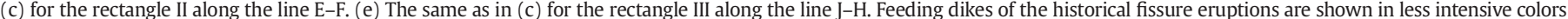

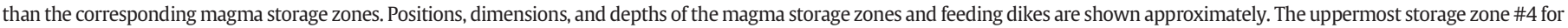
the high-Al magma was drained and destroyed during the 1975-76 eruption and the summit caldera collapse. See text for details. 
the modern topography. Clusters of local seismicity at Tolbachik (Fig. 9), which probably define the positions of several magma storage zones for the volcano (described below), are located east of both rifts. Thus the deep fault below the rifts may dip about $70^{\circ} \mathrm{E}$ (Senyukov et al., 2015).

The precursory seismicity of the 2012-13 eruption (Saltykov et al., 2012; Kugaenko et al., 2015; Senyukov et al., 2015) shows that highAl magma ascended to the surface from a magma storage zone at a depth of about $5 \mathrm{~km}$ below the summit of Plosky Tolbachik (indicated by \#3 in Fig. 9). The magma first ascended along the central conduit of the volcano. Then the feeding dyke deviated from the conduit and propagated sub-horizontally along the southwest rift at a depth about $1 \mathrm{~km}$ below sea level, as interpreted from INSAR imagery (Lundgren et al., 2015). Such vertical-to-horizontal path of magma ascent is also confirmed by Caudron et al. (2015) basing on seismic amplitude ratio analysis. The precursory seismicity of the 1975-76 Southern Breakthrough suggests that it was fed in a similar way (Fedotov et al., 2010). Obviously, before the Southern Breakthrough, a very shallow storage zone of high-Al magma existed under the volcano summit (indicated by \#4 in Fig. 9). This zone fed the lava lake activity observed on the volcano summit in 1939-1941 and 1967-1970. Storage zone \#4 was emptied and destroyed during the 1975-76 eruption and the accompanying caldera subsidence. This can explain why the long-term forecast of the next eruption, based on the average productivity rate of magma of the volcano, was incorrect. The eruption came in 2012-2013, much earlier than forecast, because a significant part of the 1975-76 Southern Breakthrough magma had come from the shallow storage zone \#4, not from \#3 at $5 \mathrm{~km}$ depth. Thus the $5-\mathrm{km}$ storage zone (\#3 in Fig. 9) that fed the 2012-13 eruption was not exhausted and needed much less time than forecast to be replenished.

The absence of involvement of a very shallow subvolcanic storage zone \#4 during the 2012-13 eruption explains a number of other features. This is probably the main reason that no new summit caldera formed; the $5 \mathrm{~km}$ chamber is probably too deep to produce a collapse caldera with the given volume of withdrawn magma (Holohan et al., 2011). It also explains the smaller size and scarcity of plagioclase phenocrysts (and crystal lapilli) in the 2012-13 products; very shallow storage zones and lakes of fluid lava have intense thermal convection that favors growth of plagioclase megacrysts. Due to the absence of a very shallow chamber before the 2012-13 eruption (that was destroyed during the previous eruption and the accompanying caldera collapse), the megacrysts had no place to grow effectively.

Several nested calderas at the summit of the volcano indicate that very shallow transient storage zones periodically form at Tolbachik. Such zones may gradually grow during the periods when long-lasting convecting lava lakes exist on the volcano summit. The very shallow storage zones and the lava lakes drain (partially or completely) during voluminous rift eruptions of high-Al magma, resulting in caldera subsidences.

The higher rates of lava discharge in 2012-13 compared to 1975-76 can be explained by the much shorter horizontal length of the feeding dike ( $8 \mathrm{vs} .28 \mathrm{~km}$ ). The shorter conduit allowed for a higher discharge due to less frictional damping, if other parameters are equal. The higher discharge rate in the 2012-13, in turn, explains the larger proportion of 'a'a versus pahoehoe, longer and broader lava tubes, and the sustained character of the lava pond in the crater of the scoria cone.

High-Al magma volumetrically dominates ( $>90 \%$ by volume) the deposits of the southwest rift and composes 100\% of the northeast rift deposits. Moreover, the high-Mg products first appeared in the southwest rift only 2000 years ago. Thus, both rift zones may have formed dominantly by radial sub-horizontal dyke intrusions of high-Al magma from the shallow magma storage zones of Plosky Tolbachik stratovolcano.

The precursory seismicity of the 1975-76 Northern Breakthrough shows that high-Mg magma ascended to the ground surface from the magma storage zone located directly below the area of the Breakthrough at a depth of approximately $20 \mathrm{~km}$ (Fedotov et al., 2010). The
high-Mg magma storage zone probably underlies the so-called Tolud seismic cluster (indicated by \#1 in Fig. 9). The steeply inclined feeder dyke propagated from the storage zone upward through a thick sequence of sedimentary rocks underlying the volcano, consistent with the abundance of sedimentary xenoliths in the erupted products of the 1975-76 Northern Breakthrough. Other high-Mg eruptions of the southwest rift (the 1941 and pre-historical) were probably fed in a similar way. The 1941 Breakthrough occurred only $4.5 \mathrm{~km}$ from Plosky Tolbachik; hence its high-Mg vertical dyke intruded near the high-Al magma chambers of the stratovolcano. Rapid ascent of the high-Mg magma from $20 \mathrm{~km}$ explains the strong explosivity of these eruptions, which were Subplinian-Ultrastrombolian with eruption clouds up to $10 \mathrm{~km}$ high that produced voluminous tephra deposits and large scoria cones.

One more chamber containing high-Mg magma (indicated by \#2 in Fig. 9) may be located about $20 \mathrm{~km}$ under the northeast rift, as indicated by a seismic cluster. However, no high-Mg basalt has erupted in the northeast rift. Possibly the present state of the northeast rift is comparable to the state of the southwest rift before 2000 years ago, i.e., before it started to erupt high-Mg magmas. Both storage zones of high-Mg magma (\#1 and \#2) may be interconnected at a depth of around $20 \mathrm{~km}$ and together may supply magma to the shallow high-Al magma storage zones of Tolbachik stratovolcano, since the high-Mg magma is parental to the high-Al magma (Portnyagin et al., 2015). This possibility is suggested by the fact that the seismic clusters above both high-Mg magma storage zones became active after initiation of the 2012-13 eruption (Droznin and Droznina, 2015), probably responding to the chamber's deflation caused by high-Mg magma migrations to replenish the high-Al magma erupted from the $5 \mathrm{~km}$ chamber (\#3 in Fig. 9).

Few products of the southwest rift have compositions intermediate between the high-Al and high-Mg magmas. However, the 1975-76 eruption demonstrated how the intermediate magmas can form. When the sub-horizontal dyke of the Southern Breakthrough propagated along the southwest rift, it crossed the sub-vertical dyke of the Northern Breakthrough that was filled with high-Mg magma. The intermingling of the two magmas produced magma of intermediate composition that erupted in small volumes at the end of the Northern Breakthrough and at the beginning of the Southern Breakthrough.

The area around Tolbachik has few earthquakes at the depths of $>25 \mathrm{~km}$ that could indicate the paths of deep magma supply into the high-Mg magma chambers. Possibly the high-Mg magma migrates laterally to the Plosky Tolbachik storage zones from the Klyuchevskoy magma system (Fedotov et al., 2010). A deep vertical feeding conduit located under Klyuchevskoy Volcano is marked by numerous earthquakes at depths of at least 30-40 km (Fig. 9).

\section{Conclusions}

The 2012-13 flank fissure eruption of Tolbachik lasted more than nine months and discharged $\sim 0.55 \mathrm{~km}^{3}$ DRE of basaltic trachyandesite magma. It is one of the most voluminous historical eruptions of mafic magma at subduction-related volcano globally, and is the second largest in Kamchatka. The eruption dynamics (voluminous long-term outpouring of fluid lava with gradually declining discharge rate and the accompanying rather mild Hawaiian-Strombolian explosive activity), can be considered typical of fissure eruptions at the volcano producing magma with the high-Al composition.

New geophysical, geological and petrological data obtained during the 2012-13 eruption together with data on the previous eruptions are consistent with the hypothesis that Plosky Tolbachik stratovolcano and its two rifts have a common, genetically integrated magma storage and transport system. Eruptions of the high-Al magma within the rifts are fed by subhorizontal injections from magma chambers of $\leq 5 \mathrm{~km}$ deep directly under Plosky Tolbachik stratovolcano. Such geometry of magma transport explains the character of the precursory seismicity 
(shallow, weak earthquakes migrating laterally from the stratocone toward the location of the upcoming breakthrough) and the relatively weak explosivity of these eruptions.

The high-Al magma resides in two magma storage zones, the lower at a depth of about $5 \mathrm{~km}$, and the upper about $0 \mathrm{~km}$ inside the volcanic edifice. The $5 \mathrm{~km}$ magma chamber is a long-lived structure, but the intra-edifice chamber is transient, forming during magma replenishment between eruptions and being destroyed by summit caldera subsidences during voluminous eruptions of high-Al magma within the rifts. Peculiarities of the dynamics of the 2012-13 eruption (very high initial discharge rate of lava, few plagioclase phenocrysts in the products, broad and long lava tubes, no summit caldera collapse) are explained by the short distance from the breakthrough to the storage zone of the high-Al magma (short sub-horizontal feeding dike), and by the absence of the shallow, intra-edifice high-Al magma chamber that was destroyed during the 1975-76 eruption and caldera subsidence.

The high-Al magma differentiates from the deeply-stored high-Mg magma while it ascends through the system of the shallow magma chambers of Plosky Tolbachik. The high-Mg magma is stored at a depth of about $20 \mathrm{~km}$, probably below the Tolud cluster of local seismicity. During some of the rift eruptions (e.g., 1941 and 1975-76 Northern Breakthrough), this magma ascends directly from the storage zone along a newly formed sub-vertical dyke that propagates upward along the plane of the deep regional fault. Such geometry of magma transport explains the character of the precursory seismicity of the Northern Breakthrough (strong earthquakes migrating vertically from the $20 \mathrm{~km}$ depths directly under the location of the upcoming breakthrough) and relatively strong explosivity of the eruptions of high-Mg magma.

The differences between the geometries of magma transport systems of the fissure eruptions of the high-Al and high-Mg magmas are clearly linked to differences in the precursors of the eruptions. These differences will help to forecast the composition and style of future eruptions of Tolbachik Volcano.

\section{Acknowledgments}

Funding for this research is from the Institute of Volcanology and Seismology, Petropavlovsk, Russia and the National Science Foundation (NSF-RAPID 0910712 to BRE). We thank S. Chirkov, Y. Bukatov, S. Mikaelov, Yu. Frolova, A. Nechaev, D. Okopny for their assistance in the field, and A. Bichenko, Y. Demyanchuk, A. Sokorenko, and D. Savelyev for sharing their field observations. Careful and constructive reviews by Donald Swanson and Margaret Hartley greatly improved the manuscript.

\section{References}

Braitseva, O.A., Melekestev, IV., Ponomareva, V.V., 1983. Age divisions of the Holocene volcanic formations of the Tolbachik Valley. In: Markhinin, E.K., Fedotov, S.A. (Eds.) The Great Tolbachik Fissure Eruption: Geological and Geophysical Data 1975-1976. Cambridge Earth Science Series, pp. 83-95.

Braitseva, O.A., Melekestsev, I.V., Flerov, G.B., Ponomareva, V.V., Sulerzhitsky, L.D. Litasova, S.N., 1984. Holocene volcanism of the Tolbachik regional zone of cinder cones. In: Fedotov, S.A. (Ed.), Great Tolbachik Fissure Eruption, Kamchatka, 1975-1976. Nauka, Moscow, pp. 177-209 (In Russian).

Caudron, C., Taisne, B., Kugaenko, Y., Saltykov, V., 2015. Magma migration at the onset of the 2012-13 Tolbachik eruption revealed by Seismic Amplitude Ratio Analyses (this volume)

Churikova, T.G., Gordeychik, B.N., Edwards, B.R., Ponomareva, V.V., Zelenin, E., 2015. The Tolbachik volcanic complex: a review of the petrology, volcanology and eruption history prior to the 2012-2013 eruption. J. Volcanol. Geotherm. Res. (this volume).

Droznin, VA Droznina, S, 2015. Spatial and temporal distribution of earthquakes during the 2012-13 fissure eruption of Tolbachik Volcano. J. Volcanol. Geotherm. Res. (this volume).

Droznin, V.A., Dubrovskaya, I.K., Chirkov, S.A., 2014. Results of infrared surveys of 2012-13 Tolbachik Fissure Eruption. Conference "Volcanism and connected processes", Petropavlovsk-Kamchatsky, Russia (in Russian).

Dvigalo, V.N., Fedotov, S.A., Chirkov, A.M., 1991. Plosky Tolbachik. In: Fedotov, S.A. Masurenkov, Yu.P. (Eds.), Active Volcanoes of Kamchatka vol. 1. Nauka, Moscow, pp. 198-211.
Dvigalo, V.N., Svirid, I.Yu., Shevchenko, A.V., 2014. The first quantitative estimates of parameters for the Tolbachik Fissure Eruption of 2012-2013 from aerophotogrammetric observations. J. Volcanol. Seismol. 8 (5), 261-268.

Edwards, B., Belousov, A., Belousova, M., Volynets, A., Melnikov, D., Chirkov, S., Senyukov, S., Gordeev, E., Muraviev, Ya, Izbekov, P., Demianchuk, Yu., 2013. Another great Tolbachik eruption? Eos 94 (21), 189-191.

Edwards, B.R., Belousov, A., Belousova, M., 2014. Propagation style controls lava-snow interactions. Nat. Commun. 5, 5666

Edwards, B.R., Belousov, A., Belousova, M., Melnikov, D., 2015. Observations on lava, snowpack and lava-snowpack interactions during the 2012-13 Tolbachik eruption, Klyuchevskoy Group of Volcanoes, Kamchatka, Russia. J. Volcanol. Geotherm. Res. (this volume).

Ermakov, V.A., Gontovaya, L.I., Senyukov, S.L., 2014. Tectonics and magma chambers of the recent Tolbachik Fissure Eruption (Kamchatka Peninsula). Izv. Atmos. Oceanic Phys. 50 (8), 745-765.

Fedotov, S.A. (Ed.), 1984. The 1975-1976 Large Tolbachik Fissure Eruption in Kamchatka. Moscow, Nauka (637 pp. (in Russian))

Fedotov, S.A., Markhinin, Y.K. (Eds.), 1983. The Great Tolbachik Fissure Eruption, 1975-1976. Cambridge University Press, New York (341 pp.)

Fedotov, S.A., Chirkov, A.M., Gusev, N.A., Kovalev, G.N., Slezin, Y.B., 1980. The large fissure eruption in the region of Plosky Tolbachik Volcano in Kamchatka, 1975-1976. Bull. Volcanol. 43 (1), 47-60.

Fedotov, S.A., Balesta, S.T., Dvigalo, V.N., Razina, A.A., Flerov, G.B., Chirkov, A.M., 1991. New Tolbachik volcanoes. Active Volcanoes of Kamchatka vol. 1. Nauka, Moscow, pp. 275-279.

Fedotov, S.A., Zharinov, N.A., Gontovaya, L.I., 2010. The magmatic system of the Klyuchevskaya Group of Volcanoes inferred from data on its eruptions, earthquakes, deformation, and deep structure. J. Volcanol. Seismol. 4 (1), 1-33.

Flerov, G.B., Andreev, V.N., Budnikov, V.A., Tsyurupa, A.I., 1984. Petrology of the eruption products. In: Fedotov, S.A. (Ed.), Great Tolbachik Fissure Eruption, Kamchatka, 1975-1976. Nauka, Moscow, pp. 223-284 (In Russian).

Guschenko, I.I., 1979. Eruptions of the Volcanoes of the World (catalog). Nauka, Moscow (476 pp.).

Holohan, E.P., Schöpfer, M.P.J., Walsh, J.J., 2011. Mechanical and geometric controls on the structural evolution of pit crater and caldera subsidence. J. Geophys. Res. 116, B07202.

Krasheninnikov, S.P., 1764. History of Kamchatka and the Kurilsky Islands, With the Countries Adjacent (London).

Kugaenko, Yu, Titkov, N., Saltykov, V., 2015. New unrest of the Tolbachik volcanic zone in 2012 revealed by parameters of local seismicity and GPS data. J. Volcanol. Geotherm. Res. (this volume)

Le Maitre, R.W., 1989. A classification of the igneous rocks and glossary of terms. Recommendations of the International Union of Geological Sciences on the Systematics of Igneous Rocks. Blackwell Scientific Publications, Oxford (256 pp.)

Lundgren, P., Kiryukhin, A., Milillo, A.P., Samsonov, S., 2015. Dike model for the 2012-2013 Tolbachik eruption constrained by satellite radar interferometry observations. J. Volcanol. Geotherm. Res. (this volume).

Melekestsev, I.V., Krayevaya, T.C., Braitseva, O.A., 1970. Relief and Deposits of Young Volcanic Regions of Kamchatka. Nauka, Moscow (104 pp. (in Russian)).

Melnikov, D., Volynets, A., 2015. Remote sensing and petrological observations on the 2012-2013 fissure eruption at Tolbachik Volcano, Kamchatka: implications to the reconstruction of the eruption chronology. J. Volcanol. Geotherm. Res. (this volume)

Ozerov, A.Y., 2000. The evolution of high-alumina basalts of the Klyuchevskoy Volcano, Kamchatka, Russia, based on microprobe analyses of mineral inclusions. J. Volcanol. Geotherm. Res. 95, 65-79.

Piip, B.I., 1946. A new flank crater on Plosky Tolbachik Volcano. Bull. Vol. Obs. Kamchatka 13, 10-21 (in Russian).

Piip, B.I., 1956. Klyuchevskaya Sopka and its eruptions in 1944-1945 and in the past. Transactions of Volcanological Laboratory AN SSSR 11 (in Russian).

Portnyagin, M., Bindeman, I., Hoernle, K., Hauff, F., 2007. Geochemistry of primitive lavas of the Central Kamchatka Depression: magma generation at the edge of the Pacific Plate. In: Eichelberger, J., Izbekov, P., Kasahara, M., Lees, J., Gordeev, E. (Eds.), Volcanism and Tectonics of the Kamchatka Peninsula and Adjacent Arcs. AGU Monograph Series 172, pp. 199-239.

Portnyagin, M., Duggen, S., Hauff, F., Mironov, N., Bindeman, I., Thirlwall, M., Hoernle, K., 2015. Geochemistry of the Late Holocene rocks from the Tolbachik volcanic field, Kamchatka: towards quantitative modelling of subduction-related open magmatic systems. J. Volcanol. Geotherm. Res. (this volume)

Saltykov, V.A., Kugaenko, YuA., Voropaev, P., 2012. Seismic anomaly preceding New Fissure Tolbachik eruption in 2012. Vestnik KRAUNZ 2, 16-19.

Samoylenko, S., Melnikov, D., Magus'kin, M., Ovsyannikov, A., 2012. The beginning of new fissure Tolbachik eruption in 2012. Vestn. Kraunz 2, 20-22 (in Russian).

Senyukov, S.L., Nuzdina, I.N., Droznina, S.Ya, Garbuzova, V.T., Kozhevnikova, T.Yu, Sobolevskaya, O.V., Nazarova, Z.A., Bliznetsov, V.E., 2015. Seismic monitoring of the Plosky Tolbachik eruption in 2012-13 (Kamchatka Peninsula, Russia). J. Volcanol. Geotherm. Res. (this volume).

Steller, G.W., 1774. Beschreibung von dem Lande Kamtschatka (Frankfurt).

Steller, G.W., 2003. Steller's History of Kamchatka. Historical Translation Series vol. 12. University of Alaska Press, Fairbanks (298 pp.).

Tokarev, P.I., 1978. Prediction and characteristics of the 1975 eruption of Tolbachik Volcano, Kamchatka. Bull. Volcanol. 41 (3), 251-258.

Volynets, O.N., Flerov, G.B., Andreyev, V.N., Popolitov, E.I., Abramov, V.A., Petrov, L.L., Scheka, S.A., Selivanova, G.I., 1983. Geochemical features of the rocks of the Great Tolbachik Fissure Eruption 1975-1976 in relation to petrogenesis. In: Fedotov, S.A., Markhinin, E.K. (Eds.), The Great Tolbachik Fissure Eruption. Cambridge University Press, Cambridge, pp. 116-140. 
Volynets, A.O., Melnikov, D.V., Yakushev, A.I., 2013. First data on composition of the volcanic rocks of the IVS 50th anniversary Fissure Tolbachik eruption (Kamchatka). Dokl. Earth Sci. part 1, 953-957.

Volynets, A., Edwards, B., Melnikov, B., Yakushev, A., Griboedova, I., 2015. Monitoring of the volcanic rock compositions during the 2012-2013 fissure eruption at Tolbachik Volcano, Kamchatka. J. Volcanol. Geotherm. Res. (this volume).
Yogodzinski, G.M., Lees, J.M., Churikova, T.G., Dorendorf, F., Wöerner, G., Volynets, O.N. 2001. Geochemical evidence for the melting of subducting oceanic lithosphere at plate edges. Nature 409 (6819), 500-504.

Zelenski, M., Malik, N., Taran, Yu., 2014. Emissions of trace elements during the 2012-2013 effusive eruption of Tolbachik Volcano, Kamchatka: enrichment factors, partition coefficients and aerosol contribution. J. Volcanol. Geotherm. Res. 285, 136-149. 